\title{
Abomasal infusion of corn starch and $\beta$-hydroxybutyrate in early-lactation Holstein-Friesian dairy cows to induce hindgut and metabolic acidosis
}

\author{
Sanne van Gastelen, ${ }^{1 *} \odot$ Jan Dijkstra, ${ }^{2} \odot$ Sven J. J. Alferink, ${ }^{2} \odot$ Gisabeth Binnendijk, ${ }^{1}$ Kelly Nichols, ${ }^{2} \odot$ \\ Tamme Zandstra, ${ }^{2}$ and André Bannink ${ }^{1}$ \\ ${ }^{1}$ Wageningen Livestock Research, Wageningen University \& Research, PO Box 338, $6700 \mathrm{AH}$, Wageningen, the Netherlands \\ ${ }^{2}$ Animal Nutrition Group, Wageningen University \& Research, PO Box 338, $6700 \mathrm{AH}$, Wageningen, the Netherlands
}

\begin{abstract}
The objectives of this study were to induce hindgut and metabolic acidosis via abomasal infusion of corn starch and $\beta$-hydroxybutyrate (BHB), respectively, and to determine the effects of these physiological states in early-lactation dairy cows. In a $6 \times 6$ Latin square design, 6 rumen-fistulated Holstein-Friesian dairy cows $(66 \pm 18 \mathrm{~d}$ in milk) were subjected to $5 \mathrm{~d}$ of continuous abomasal infusion treatments followed by $2 \mathrm{~d}$ of rest. The abomasal infusion treatments followed a 3 $\times 2$ factorial design, with 3 levels of corn starch and 2 levels of BHB. The infusions were water as control, 1.5 $\mathrm{kg}$ of corn starch/d, $3.0 \mathrm{~kg}$ of corn starch/d, $8.0 \mathrm{~mol}$ $\mathrm{BHB} / \mathrm{d}, 1.5 \mathrm{~kg}$ of corn starch $/ \mathrm{d}+8.0 \mathrm{~mol} \mathrm{BHB} / \mathrm{d}$, or $3.0 \mathrm{~kg}$ of corn starch $/ \mathrm{d}+8.0 \mathrm{~mol} \mathrm{BHB} / \mathrm{d}$. A total mixed ration consisting of $35.0 \%$ grass silage, $37.4 \%$ corn silage, and $27.6 \%$ concentrate (on a dry matter basis) was fed at $90 \%$ of ad libitum intake of individual cows. The experiment was conducted in climate respiration chambers to facilitate determination of energy and $\mathrm{N}$ balance. Fecal $\mathrm{pH}$ decreased with each level of corn starch infused into the abomasum and was $6.49,6.00$, and 5.15 with $0.0,1.5$, and $3.0 \mathrm{~kg}$ of corn starch/d, respectively, suggesting that hindgut acidosis was induced with corn starch infusion. No systemic inflammatory response was observed and the permeability of the intestine or hindgut epithelium was not affected by the more acidic conditions. This induced hindgut acidosis was associated with decreased digestibility of nutrients, except for crude fat and NDF, which were not affected. Induced hindgut acidosis did not affect milk production and composition and energy balance, but increased milk $\mathrm{N}$ efficiency. Abomasal infusion of BHB resulted in a compensated metabolic acidosis, which was characterized by a clear disturbance of acidbase status (i.e., decreased blood total $\mathrm{CO}_{2}, \mathrm{HCO}_{3}$, and
\end{abstract}

Received February 18, 2021.

Accepted July 7, 2021.

*Corresponding author: sanne.vangastelen@wur.nl base excess, and a tendency for decreased urinary $\mathrm{pH}$ ), whereas blood $\mathrm{pH}$ remained within a physiologically normal range. Abomasal infusion of $\mathrm{BHB}$ resulted in increased concentrations of BHB in milk and plasma, but both remained well below the critical threshold values for subclinical ketosis. Induced compensated metabolic acidosis, as a result of abomasally infused $\mathrm{BHB}$, increased energy retained as body fat, did not affect milk production and composition or inflammatory response, but increased intestinal permeability.

Key words: dairy cow, early lactation, metabolic acidosis, hindgut acidosis

\section{INTRODUCTION}

In early lactation, the rapid increase in energy requirements for milk production by dairy cattle cannot be met by an increase in feed intake alone (van Knegsel et al., 2007a). To compensate for this energy deficit, dairy cows mobilize body fat and, as a result, the concentration of nonesterified fatty acids (NEFA) is elevated in blood. When the capacity of the liver to oxidize these NEFA is exceeded, remaining NEFA are stored as triglycerides in the liver or are converted into ketone bodies that enter circulation (Bell, 1995). Although ketone bodies can be used as an alternative form of energy by some tissues (e.g., brain; Laffel, 1999), the utilization of ketone bodies is limited. Excess concentration of ketone bodies in blood increases the risk for ketosis (Duffield, 2000). Subclinical ketosis in early lactation affects 40 to $60 \%$ of cows in herds undergoing repeated testing (Emery et al., 1964; Simensen et al., 1990), which is much higher than the typical 2 to $15 \%$ incidence of clinical ketosis (Duffield, 2000). The ketone bodies BHB and acetoacetate are organic acids (pKa of 3.6 and 4.7, respectively) that dissociate almost fully at physiological $\mathrm{pH}$ (Laffel, 1999). If the associated rise in hydrogen ion concentration in blood exceeds blood buffering capacity during periods of high blood ketone concentrations, metabolic acidosis may result (Hood and Tannen, 1994). 
It has only been relatively recently recognized that strategies to prevent diseases such as ketosis in earlylactation cows (i.e., increasing the energy density of rations with fermentable carbohydrates) are closely linked with the gastrointestinal function and health of dairy cows (e.g., Enemark, 2008; Mulligan and Doherty, 2008). Hindgut fermentation has been associated with high intake of starch and other fermentable substrates that are not fully degraded in the rumen (Gressley et al., 2011). As dairy cows have relatively limited amylolytic activity in the small intestines (Matthé et al., 2001), incompletely degraded and digested substrates flow into the hindgut where fermentation of these substrates occurs. This increases the risk of hindgut acidosis, which can be defined as an accumulation of organic acids and a subsequent decrease in digesta pH (Gressley et al., 2011). Acidosis in the hindgut can potentially cause dysbiosis in the microbial community and epithelial damage, and consequently can affect animal production and health (Plaizier et al., 2018).

Recently, van Gastelen et al. (2021) showed that both hindgut acidosis and metabolic acidosis were associated with changes in feed intake, apparent totaltract digestibility (ATTD) of nutrients, milk production and composition, and $\mathrm{N}$ and energy partitioning. Importantly, van Gastelen et al. (2021) demonstrated that metabolic acidosis became more severe when dairy cows also experienced hindgut acidosis, suggesting that a relation may exist between acidosis in the hindgut and the occurrence of metabolic acidosis. In the study of van Gastelen et al. (2021), metabolic acidosis was induced by infusing ammonium chloride and hindgut acidosis was induced by infusing ground corn. It is unclear whether the relation between hindgut acidosis and metabolic acidosis also exists when metabolic acidosis is induced via accumulation of ketone bodies (i.e., a different mechanism that can affect the acid-base status of a dairy cow). It also remains unclear from the study of van Gastelen et al. (2021) whether there is a dose effect of the amount of starch infused and the severity of hindgut acidosis. Therefore, the aims of the current study were to (1) induce hindgut and metabolic acidosis via abomasal infusion of corn starch and BHB, respectively, and (2) determine the effects of these physiological states on feed intake, ATTD of nutrients, energy and $\mathrm{N}$ partitioning, milk production and composition, acid-base status, respiratory and metabolic status, and ruminal and hindgut fermentation characteristics. We hypothesized that abomasally infused corn starch would be fermented in the hindgut, produce VFA, and subsequently decrease digesta $\mathrm{pH}$, resulting in hindgut acidosis and compromised intestinal permeability. Abomasal infusion of BHB was expected to disturb the acid-base status of the dairy cows, resulting in metabolic acidosis (i.e., a decreased blood $\mathrm{pH}$ ). When corn starch and BHB were infused simultaneously into the abomasum, we expected to induce hindgut and metabolic acidosis. We expected the metabolic acidosis to be more severe with both corn starch and BHB infusion compared with only BHB infusion because of a combined effect of both types of acidosis on the acid-base status of the cow.

\section{MATERIALS AND METHODS}

\section{Experimental Design and Housing}

The experiment was conducted from August until October 2019 at the animal research facilities of Wageningen University \& Research (Wageningen, the Netherlands), under the Dutch Law on Animal Experiments in accordance with European Union Directive 2010/63, and was approved by the Central Committee of Animal Experiments (The Hague, the Netherlands; 2018.D-0013.002).

Six rumen-fistulated, multiparous Holstein-Friesian dairy cows (second parity $\mathrm{n}=5$, third parity $\mathrm{n}=1$ ) producing $28.8 \pm 4.96 \mathrm{~kg} / \mathrm{d}$ at $66 \pm 18$ DIM (average \pm $\mathrm{SD})$ at the beginning of the experiment were randomly assigned to a $6 \times 6$ Latin square design with 6 treatments. Each experimental period $(\mathrm{n}=6)$ consisted of $5 \mathrm{~d}$ of continuous abomasal infusion followed by $2 \mathrm{~d}$ of rest. Cows were adapted to the experimental conditions for $19 \mathrm{~d}$ before the first experimental period. For the first $14 \mathrm{~d}$ of adaptation, cows were housed individually in tiestalls to become adapted to the basal diet as well as the restriction in movement. For the last $5 \mathrm{~d}$ of adaptation as well as for the 6 consecutive experimental periods, cows were housed individually in identical climate respiration chambers (CRC) to measure, among other variables, the effect of abomasally infused BHB and corn starch on the energy and $\mathrm{N}$ partitioning of the dairy cows.

\section{Diet and Feeding}

Cows were fed a TMR consisting of $35.0 \%$ grass silage, $37.4 \%$ corn silage, and $27.6 \%$ concentrate on a DM basis (Table 1). To determine the ATTD of nutrients, $\mathrm{TiO}_{2}$ was included in the concentrate $(5 \mathrm{~g} /$ $\mathrm{kg}$ DM) as an external marker. The concentrate was in meal form and produced by Research Diet Services (RDS BV) in a single batch. The diet was formulated to meet 101 and $96 \%$ of $\mathrm{NE}_{\mathrm{L}}$ (Van Es, 1978) and intestinal digestible protein requirements (Van Duinkerken et al., 2011), respectively, for cows consuming $19.0 \mathrm{~kg}$ of $\mathrm{DM} / \mathrm{d}$ and producing $33 \mathrm{~kg} / \mathrm{d}$ of milk containing $4.5 \%$ 
fat and 3.5\% protein (i.e., mean DMI and milk production measured during the first weeks of lactation of the cows that would potentially enter this study).

Cows were fed ad libitum for the first $10 \mathrm{~d}$ of the 19-d adaptation period. Intake during the final $5 \mathrm{~d}$ of this 10-d ad libitum intake period was used to calculate a $10 \%$ daily intake restriction for individual cows. From d 11 onward, cows were fed this fixed amount for the remainder of the adaptation and experimental periods. The grass silage, corn silage, and water were mixed 3 times weekly using a self-propelled mixer wagon (Strautmann Verti-Mix 500) equipped with a cutter loader system and an electronic weighing scale. The forage mixture was fed directly after preparation or stored in a cooling unit at $6^{\circ} \mathrm{C}$ to be used for future feedings for a maximum of $2 \mathrm{~d}$. Forage and concentrate portions were manually mixed into a TMR for individual cows and the fresh TMR was fed twice daily at 0500 and $1530 \mathrm{~h}$. Before providing fresh feed, feed refusals were collected and weighed to determine daily feed intake. For a $60-\mathrm{h}$ period over d 3 to 6 of each experimental period $(1700 \mathrm{~h}$ on d 3 until $0500 \mathrm{~h}$ on d 6 ), cows were fed using an automated feeding system that dispensed equal portions of feed every $2 \mathrm{~h}$ to promote metabolic steady-state conditions in preparation for the blood sampling protocol described later. Cows had free access to clean drinking water throughout the entire experiment.

\section{Abomasal Infusions}

The abomasal infusion treatments followed a $3 \times$ 2 factorial design, with 3 levels of corn starch and 2 levels of $\mathrm{BHB}$, and contained corn starch, $\mathrm{BHB}$, or a combination of both. The abomasal infusion treatments were (1) $0.0 \mathrm{~kg}$ of corn starch $/ \mathrm{d}+0.0 \mathrm{~mol} \mathrm{BHB} / \mathrm{d}$, (2) $0.0 \mathrm{~kg}$ of corn starch $/ \mathrm{d}+8.0 \mathrm{~mol} \mathrm{BHB} / \mathrm{d}$, (3) $1.5 \mathrm{~kg}$ of corn starch $/ \mathrm{d}+0.0 \mathrm{~mol} \mathrm{BHB} / \mathrm{d}$, (4) $1.5 \mathrm{~kg}$ of corn starch $/ \mathrm{d}+8.0 \mathrm{~mol} \mathrm{BHB} / \mathrm{d}$, (5) $3.0 \mathrm{~kg}$ of corn starch $/ \mathrm{d}$ $+0.0 \mathrm{~mol} \mathrm{BHB} / \mathrm{d}$, and (6) $3.0 \mathrm{~kg}$ of corn starch $/ \mathrm{d}+$ $8.0 \mathrm{~mol} \mathrm{BHB} / \mathrm{d}$ (Table 2). We based the dose of BHB on the assumption that, on average, $28 \mathrm{~kg}$ of body fat would be mobilized over a period of $8 \mathrm{wk}$ (i.e., $500 \mathrm{~g}$ of body fat/d; Tamminga et al., 1997; van Knegsel et al., $2007 \mathrm{a})$, resulting in the production of $6.3 \mathrm{~mol} \mathrm{BHB} / \mathrm{d}$. To increase the likelihood of inducing metabolic acidosis, the BHB dose in the present study is about $25 \%$ more than the estimated level of endogenous BHB production. With the corn starch dose, we aimed to achieve an amount of starch entering the small intestine (i.e., abomasally infused corn starch plus starch from basal TMR) that was within the range of total postru-

Table 1. Chemical composition ( $\mathrm{g} / \mathrm{kg}$ of $\mathrm{DM}$, unless stated otherwise) of the TMR ingredients (grass silage, corn silage, and concentrates; analyzed) and of the complete $\mathrm{TMR}^{1}$ (calculated)

\begin{tabular}{lcccc}
\hline Item & Grass silage $^{2}$ & Corn silage $^{3}$ & Concentrate $^{4}$ & TMR \\
\hline $\mathrm{DM}(\mathrm{g} / \mathrm{kg}$ of product) & 404 & 310 & 887 & 364 \\
$\mathrm{OM}$ & 899 & 953 & 903 & 920 \\
$\mathrm{CP}$ & 195 & 97 & 187 & 156 \\
Crude fat & 45 & 31 & 39 & 38 \\
Gross energy (MJ/kg of DM) & 19.6 & 19.1 & 18.0 & 19.0 \\
$\mathrm{NDF}$ & 405 & 383 & 235 & 350 \\
$\mathrm{ADF}$ & 214 & 230 & 120 & 194 \\
$\mathrm{ADL}$ & 7 & 12 & 12 & 10 \\
Starch & -5 & 270 & 170 & 148 \\
Sugar $_{\text {NE }}^{6}(\mathrm{MJ} / \mathrm{kg}$ of DM) & 120 & -5.8 & 112 & 73 \\
DVE $^{7}$ & 6.9 & 57 & 7.5 & 7.0 \\
OEB $^{8}$ & 73 & -36 & -44 & 92 \\
\hline
\end{tabular}

${ }^{1}$ The TMR was composed of $31.5 \%$ grass silage, $43.9 \%$ corn silage, $11.3 \%$ concentrate, and $13.3 \%$ water on a product basis, which equals $350 \mathrm{~g} / \mathrm{kg}$ DM grass silage, $374 \mathrm{~g} / \mathrm{kg}$ DM corn silage, and $276 \mathrm{~g} / \mathrm{kg}$ DM concentrate. ${ }^{2}$ Ensiling characteristics: acetic acid $=7 \mathrm{~g} / \mathrm{kg} \mathrm{DM}$, lactic acid $=18 \mathrm{~g} / \mathrm{kg} \mathrm{DM}$, ammonia- $\mathrm{N}=7 \%$ total N, and $\mathrm{pH}=5.8$.

${ }^{3}$ Ensiling characteristics: acetic acid $=11 \mathrm{~g} / \mathrm{kg} \mathrm{DM}$, lactic acid $=63 \mathrm{~g} / \mathrm{kg} \mathrm{DM}$, ammonia- $\mathrm{N}=6 \%$ total N, and $\mathrm{pH}=3.8$.

${ }^{4}$ Concentrate contained $(\mathrm{g} / \mathrm{kg} \mathrm{DM})$ : sugar beet pulp $=325$, barley $=300$, rumen-protected soybean meal $($ Mervobest, NuScience $)=200$, palm kernel flakes $=60$, molasses $=50$, sunflower oil $=20, \mathrm{CaCO}_{3}=15, \mathrm{MgO}$ $=8.0$, trace mineral and vitamin $\operatorname{mix}=8.0, \mathrm{NaCl}=7.0, \mathrm{NaHCO}_{3}=2.0$, and $\mathrm{TiO}_{2}=5.0$.

${ }^{5}$ Not determined.

${ }^{6}$ van Es, 1978.

${ }^{7}$ Intestinal digestible protein (van Duinkerken et al., 2011).

${ }^{8}$ Rumen-degraded protein balance (van Duinkerken et al., 2011). 
minal starch digestion reported for lactation dairy cows fed large amounts of corn grain (maximum of $5.0 \mathrm{~kg} / \mathrm{d}$; Reynolds et al., 1997), but which would (according to van Gastelen et al., 2021) likely result in hindgut acidosis. The treatments were administered in 20-L batches that were replenished daily and infused at a rate ranging from 868 to $1,024 \mathrm{~g} / \mathrm{h}$ (Table 2) to facilitate $5 \mathrm{~d}$ of continuous infusion $(0900 \mathrm{~h}$ on d 1 until $0900 \mathrm{~h}$ on d 6 of each experimental period). To compensate the cation $\mathrm{Na}^{+}$of Na-BHB (potentially affecting the acidbase status of the cows when not compensated), $8 \mathrm{~mol}$ of $\mathrm{NH}_{4} \mathrm{Cl}$ was added to the Na-BHB containing treatments, where $\mathrm{Cl}^{-}$could function as the compensating anion. To compensate for the salts in the Na-BHB containing treatments $\left(\mathrm{Na}\right.$ of $\mathrm{Na}-\mathrm{BHB}$ and $\mathrm{Cl}$ of $\mathrm{NH}_{4} \mathrm{Cl}$; potentially affecting the water balance of the cows when not compensated), $8 \mathrm{~mol} \mathrm{NaCl}$ was added to the treatments without Na-BHB. The infusion treatments were subsequently designed to be isonitrogenous, using urea to compensate the $\mathrm{N}$ content of $\mathrm{NH}_{4} \mathrm{Cl}$ and corn starch. Unfortunately, final infused treatments were not completely iso- $\mathrm{N}$, where the amount of $\mathrm{N}$ infused varied between 113.0 and $113.9 \mathrm{~g} / \mathrm{d}$ (Table 2). To each treatment, $48 \mathrm{~g}$ of Co-EDTA/d was added as a marker for intestinal permeability [method adopted from Amado et al. (2019) and Wilms et al. (2019)]. Eighty grams of carboxymethylcellulose/d (Acros Organics) was added to increase the viscosity of the treatments (i.e., to minimize settlement of particles) to facilitate homogeneous infusions.

The abomasal infusion technique was identical to the technique described by van Gastelen et al. (2021). Briefly, infusion lines were placed in the abomasum via the ruminal cannula $2 \mathrm{~d}$ before the first experimental period and were checked twice daily for patency (i.e., by checking the peristaltic pumps, the realized amount infused in comparison with the target amount at that moment, and the infusion line, inside and outside the cows for knits or knots) and position (i.e., by opening the rumen fistula and following the infusion line to check placement in the abomasum). The infusion device was constructed from $200 \mathrm{~cm}$ of braided polyvinyl chloride hose attached to the rumen cannula plug at the proximal end and a flexible disk (equipped with holes to allow digesta passage) at the distal end to secure its placement through the sulcus omasi. The flexible disk was $12 \mathrm{~cm}$ in diameter and made of plastisol (Bar Diamond Inc.). The infusion lines (Tygon S3 E-3603, $3.2 \mathrm{~mm}$ i.d., $6.4 \mathrm{~mm}$ o.d. for the treatments without corn starch; Tygon S3 E-3603, $4.8 \mathrm{~mm}$ i.d., $8.0 \mathrm{~mm}$ o.d. for treatments with corn starch; VWR) were connected between the treatment solutions and the multichannel peristaltic pumps with luer-to-tubing connectors. The infusion lines were subsequently inserted into the

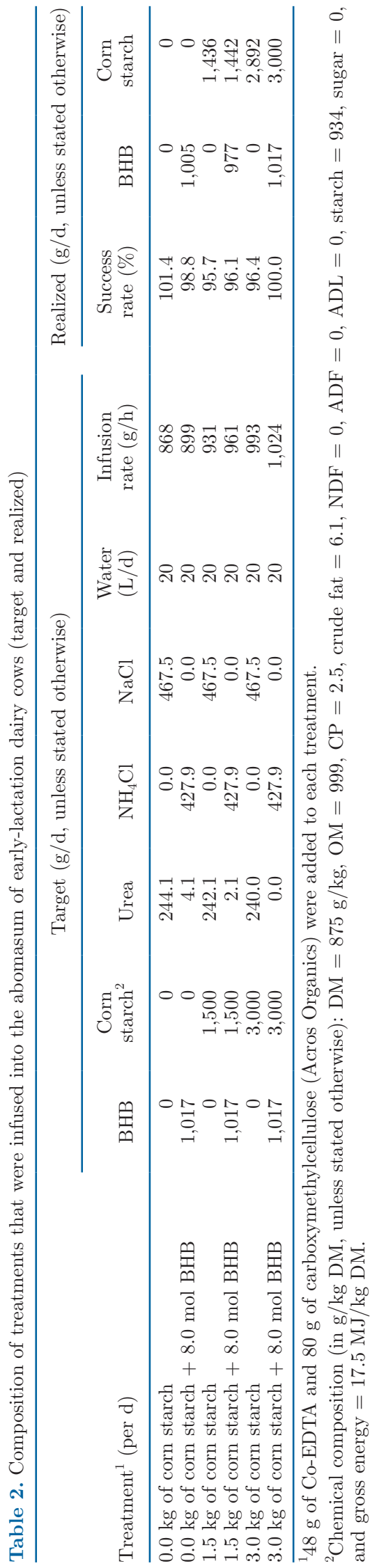


braided polyvinyl chloride hose feeding into the rumen cannula. Treatments containing corn starch were maintained in suspension by continuous stirring.

\section{Climate Respiration Chambers}

A detailed description of the CRC design and gas measurements has been reported by Heetkamp et al. (2015) and van Gastelen et al. (2015). Briefly, the relative humidity and temperature in each CRC compartment was maintained at $80 \%$ and $10^{\circ} \mathrm{C}$, respectively. The CRC compartments were separated with thin walls and windows to allow audio-visual contact between cows to minimize the effects of social isolation on cow behavior, feed intake, and milk production. Cows were exposed to $16.5 \mathrm{~h}$ of light per d (0500 to $2130 \mathrm{~h}$ ).

Gas concentrations and ventilation rates were corrected for pressure, temperature, and relative humidity to obtain standard temperature pressure dew point volumes of inlet and exhaust air. The inlet and exhaust air of each CRC were sampled as described by van Gastelen et al. (2015), with a second gas analyzer used for the additional 2 CRC compartments as described by Nichols et al. (2019). Production of $\mathrm{CO}_{2}$ and $\mathrm{CH}_{4}$ and consumption of $\mathrm{O}_{2}$ were calculated from the difference between inlet and exhaust gas volumes. Once daily, calibration gases were sampled for gas analysis instead of the inlet air, and the analyzed and actual values of these calibration gases were used to correct the measured gas concentrations from the inlet air and exhaust air of the 6 CRC compartments. At the start and the end of the experiment, each CRC was checked by releasing known amounts of $\mathrm{CO}_{2}$ and comparing these values with the data from the gas analysis system to determine $\mathrm{CO}_{2}$ recovery. The average recovery of $\mathrm{CO}_{2}$ was $100.1 \%$ (ranging between 99.5 and $100.7 \%$ for individual compartments). Gas measurements during time points when staff entered the CRC compartments (maximum 30 min for milking, feeding, and checking the abomasal infusion lines) were discarded from the data analysis. Production of $\mathrm{CO}_{2}$ and $\mathrm{CH}_{4}$ and consumption of $\mathrm{O}_{2}$ were assumed to be linear between the last data point before opening and the first data point after closing the CRC.

\section{Sample Collection and Measurements}

Cows were milked twice daily at 0500 and $1530 \mathrm{~h}$ during the adaptation and experimental periods. Milk yield was recorded at each milking. Milk samples were collected at each milking $(\mathrm{n}=6)$ during the last $72 \mathrm{~h}$ of the infusion period into tubes containing sodium azide
$(5 \mu \mathrm{L})$ for preservation, and were stored no longer than $4 \mathrm{~d}$ at $4^{\circ} \mathrm{C}$ until analysis. An additional milk sample, representative to the milk production (i.e., $5 \mathrm{~g}$ sample per $\mathrm{kg}$ of milk produced), was collected at each milking from each cow during the last $72 \mathrm{~h}$ of the infusion period, pooled per cow, and stored at $-20^{\circ} \mathrm{C}$ until energy and $\mathrm{N}$ analyses.

Fecal samples were collected immediately before each milking $(\mathrm{n}=6)$ during the last $72 \mathrm{~h}$ of the infusion period by rectal grab sampling. Feces was scored for consistency using a fecal consistency scale (1-5 scale) according to Ireland-Perry and Stallings (1993) and Zaaijer et al. (2001), where $1=$ runny, liquid consistency, spreads readily; $2=$ thin, soft, and loose consistency, may pile slightly and spreads moderately; $3=$ soft and loose, but slightly firm (not hard) consistency, piles but spreads slightly; $4=$ thick and firm consistency, piles and hardly spreads; and $5=$ dry: hard, dry, and stiff consistency, original form not distorted. Fecal samples were pooled into a composite sample by cow and infusion period, which was stored at $-20^{\circ} \mathrm{C}$ until analysis for composition (i.e., for determination of ATTD of nutrients as well as energy and $\mathrm{N}$ balance).

Before the last 2 milking events of the infusion period, feces, urine, and ruminal fluid samples were collected. The fecal sample $(\sim 250 \mathrm{~g})$ was collected by rectal grab sampling and the urine sample was collected by stimulating the dairy cows to urinate by rubbing the perineum using a vertical movement. The ruminal fluid sample $(\sim 200 \mathrm{~mL})$ was obtained as described by van Zijderveld et al. (2011), and was composed of equal volumes collected from the front and middle of the ventral sac and from the cranial sac of the rumen. Immediately after collection, each sample was mixed and their $\mathrm{pH}$ measured using an electronic pH meter (HI9024C, Hanna Instruments). Subsequently, the urine sample was discarded and a subsample of feces $(\sim 100 \mathrm{~g})$ was collected. A subsample of the ruminal fluid $(600 \mu \mathrm{L})$ was collected and acidified with an equal volume of 0.85 $\mathrm{mg} / \mathrm{L}$ orthophosphoric acid containing $19.68 \mathrm{~m} M$ isocaproic acid as an internal standard. The subsamples of feces and ruminal fluid ( 2 subsamples each per cow per infusion period, representing the last 2 milking events) were stored at $-20^{\circ} \mathrm{C}$ until VFA analysis.

Samples of grass silage, corn silage, and concentrate were collected 3 times weekly during feed preparation. These samples were pooled per experimental period and stored at $-20^{\circ} \mathrm{C}$ until analysis. During the last $72 \mathrm{~h}$ of the infusion period in the CRC, feed refusals were collected twice daily (0500 and $1530 \mathrm{~h}$ ), weighed, and stored at $4^{\circ} \mathrm{C}$. At the end of each experimental period, these daily orts were pooled per cow, mixed, subsampled, and stored at $-20^{\circ} \mathrm{C}$ until analysis. 
Measurements of $\mathrm{CH}_{4}$ and $\mathrm{CO}_{2}$ production and $\mathrm{O}_{2}$ consumption were based on data recorded from $\mathrm{d} 4$ $(0800 \mathrm{~h})$ through d $6(0800 \mathrm{~h})$ of each experimental period, whereas energy and $\mathrm{N}$ balance and the ATTD of nutrients were based on manure and fecal samples collected from d $3(1000 \mathrm{~h})$ through d 6 (0900 h). Cows were weighed at the start and at the end of each balance period. Each CRC compartment was cleaned at $0900 \mathrm{~h}$ on $\mathrm{d} 3$ (taking approximately $60 \mathrm{~min}$ ) to remove manure collected from the end of the previous period to facilitate a new total collection period. The manure (feces and urine) produced during the balance period (i.e., $1000 \mathrm{~h}$ on d 3 through $0900 \mathrm{~h}$ on $\mathrm{d} 6$ ) was totally collected, weighed, mixed, subsampled, and stored at $-20^{\circ} \mathrm{C}$ until analysis. To quantify the contribution of $\mathrm{N}$ from volatilized ammonia appearing from excreted and mixed feces and urine, samples of condensed water from the chamber heat exchanger and from a $25 \%$ sulfuric acid solution (wt/wt), through which aerial ammonia in outflowing air was trapped, were collected. This is according to Mesgaran et al. (2020). The total amount of condensed water was recorded and a representative sample was collected at the end of each balance period for each CRC compartment. For the $25 \%$ sulfuric acid solution, we recorded per each balance period and for each CRC compartment the amount of air flowing through and the weight of the sample collected. Both types of samples were stored at $4^{\circ} \mathrm{C}$ until analysis.

On d 5 of each experimental period, blood samples were collected from the coccygeal vessels (assumed mixture of arterial and venous blood with negligible metabolism across the tissues of the tail; Emery et al., 1965) into 10-mL sodium heparin and potassium EDTA Vacutainers (Becton Dickinson) at 0800, 1000, 1200, and $1400 \mathrm{~h}$. At each sampling moment, a subsample was collected immediately from the heparin Vacutainer and analyzed by a handheld VetScan i-STAT 1 analyzer (ABAXIS Inc.) using disposable G3+ cartridges [analyzing whole blood for $\mathrm{pH}$, partial pressure $\mathrm{CO}_{2}$ $(\mathrm{mmHg})$, partial pressure $\mathrm{O}_{2}(\mathrm{mmHg})$, base excess $(\mathrm{mmol} / \mathrm{L}) \mathrm{HCO}_{3}(\mathrm{mmol} / \mathrm{L})$, total $\mathrm{CO}_{2}(\mathrm{mmol} / \mathrm{L})$, and $\mathrm{O}_{2}$ saturation (\%); Abbott] and CHEM 8+ cartridges [analyzing whole blood for $\mathrm{Na}(\mathrm{mmol} / \mathrm{L}), \mathrm{K}(\mathrm{mmol} / \mathrm{L})$, $\mathrm{Cl}(\mathrm{mmol} / \mathrm{L})$, ionized $\mathrm{Ca}(\mathrm{mmol} / \mathrm{L})$, glucose $(\mathrm{mg} /$ $\mathrm{dL})$, urea nitrogen $(\mathrm{mg} / \mathrm{dL})$, creatinine $(\mathrm{mg} / \mathrm{dL})$, hematocrit (\% PCV), hemoglobin ( $\mathrm{g} / \mathrm{dL})$, and anion gap $(\mathrm{mmol} / \mathrm{L})$; Abbott]. Immediately after the subsample was collected, the heparin and potassium EDTA Vacutainers were placed in ice and subsequently centrifuged at $5,000 \times g$ for $15 \mathrm{~min}$ at room temperature. Plasma was aliquoted by time point and stored at $-20^{\circ} \mathrm{C}$ until further analysis (where each time point was analyzed separately).

\section{Analytical Procedures}

Samples of grass silage, corn silage, concentrate, feed refusals, manure, and feces were thawed at room temperature, freeze-dried until a constant weight was reached, and ground to pass a 1-mm screen using a cross beater mill for the grass silage, corn silage, and feed refusals (Peppink 100AN) and an ultra-centrifugal mill for all other samples (Retsch ZM200, Retsch GmbH). Wet chemical analysis for $\mathrm{DM}$, ash, $\mathrm{N}, \mathrm{NH}_{3} \mathrm{~N}$, starch, reducing sugars (i.e., all carbohydrates with reducing properties and soluble in $40 \%$ ethanol), crude fat, NDF, ADF, ADL, and Ti was performed as described by Nichols et al. (2018). Bomb calorimetry (ISO 9831; International Organization for Standardization, 1998; adiabatic bomb calorimeter, IKA-C700, Janke and Kunkel) was used to determine gross energy (GE) content. Crude protein was calculated as $\mathrm{N} \times 6.25$.

Grass silage, corn silage, and concentrate were analyzed for DM, ash, N, crude fat, starch (corn silage and concentrate only), sugars (grass silage and concentrate only), NDF, ADF, ADL, GE, and Ti (concentrate only). Feed refusals were analyzed for DM. Manure samples were analyzed for DM, N, and GE. Fecal samples were analyzed for DM, ash, N, crude fat, starch, NDF, GE, and Ti. In addition, samples of condensed water and the sulfuric acid solution were analyzed for N. Milk samples from individual milking events were analyzed for fat, protein, lactose, urea, and BHB content by mid-infrared spectroscopy (ISO 9622; International Organization for Standardization, 2013; Vereniging Veehouderijbelangen). Pooled milk samples were analyzed for GE and $\mathrm{N}$ in fresh material as described above. Samples of ruminal fluid and feces were analyzed for VFA as described by van Gastelen et al. (2021).

Blood plasma was analyzed by University Veterinary Diagnostic Laboratory (Utrecht, the Netherlands) for urea, insulin, BHB, NEFA, albumin, serum amyloid A (SAA), and haptoglobin. Plasma NEFA, BHB, insulin, and urea were analyzed as described by van Knegsel et al. (2007b). Plasma SAA, haptoglobin, and albumin were analyzed as described by van Gastelen et al. (2021). The intraassay coefficients of variation for SAA, haptoglobin, and albumin, were 5.0, 5.3, and $0.8 \%$, respectively. Algemeen Medisch Laboratorium (Antwerp, Belgium) analyzed blood plasma for cobalt content using inductively coupled plasma MS and a NexION 350D ICP-MS (Perkin Elmer).

\section{Calculations and Statistical Analysis}

Reported values for nutrient content of the TMR were calculated from ration composition and analyzed values 
obtained for grass silage, corn silage, and concentrate. For the grass silage and corn silage, intestinal digestible protein, rumen degradable protein balance, and $\mathrm{NE}_{\mathrm{L}}$ contents were calculated based on the chemical composition as obtained by near-infrared spectroscopy analysis (Eurofins Agro, Wageningen, the Netherlands). For the concentrate, intestinal digestible protein, rumen degradable protein balance, and $\mathrm{NE}_{\mathrm{L}}$ contents were calculated based on table values for composition of the ingredients (CVB, 2018). The ATTD of nutrients was calculated taking into account nutrient inflow from the TMR and the treatment infusions.

All variables related to feed intake, milk yield, and milk composition were averaged over the 3 -d balance period. Whole-blood constituents measured with the i-STAT as well as the plasma constituents, ruminal and fecal VFA, and ruminal, fecal, and urine $\mathrm{pH}$ were averaged over the analyzed sampling times. The variables related to energy and $\mathrm{N}$ balance were expressed per kilogram of metabolic BW $\left(\mathbf{B W}^{\mathbf{0 . 7 5}}\right)$ per day. Cow was considered the experimental unit for all variables. Data were analyzed using the MIXED procedure in SAS (version 9.4, SAS Institute Inc.). The model contained main effects and interaction effects of infusion treatment factors (BHB and corn starch) as fixed effects, and cow and period as random effects. Differences were considered significant at $P \leq 0.050$ and tendencies at $0.050<P \leq 0.100$. Multiple comparisons between treatment means were made using the Tukey-Kramer method when an effect of corn starch or a corn starch $\times$ BHB interaction was detected at $P \leq 0.050$. Treatment arrangement within the Latin square was balanced for first-order carryover effects in subsequent periods (Williams, 1949), where each treatment immediately preceded and followed every other treatment exactly once. We observed carryover effects between periods, assessed by testing for an effect of the previous treatment in the ANOVA, for blood Na (mmol/L; $P=0.023)$, anion gap $(\mathrm{mmol} / \mathrm{L} ; P=0.013)$, and SAA $(\mathrm{mg} / \mathrm{L} ; P=0.003)$.

\section{RESULTS}

\section{Nutrient Intake and Digestibility}

Nutrient intake and ATTD of nutrients were not affected by corn starch $\times$ BHB interactions, with the exception of DMI of the infusate (tendency only; $P=$ $0.088)$ and the ATTD of starch $(P=0.037$; Table 3$)$. The ATTD of starch increased in the presence of BHB, but only when combined with $3.0 \mathrm{~kg}$ of corn starch/d.

Regardless of BHB infusion, TMR DMI was lower $(P$ $=0.024)$ with infusion of $3.0 \mathrm{~kg}$ of starch $/ \mathrm{d}$ compared with $0.0 \mathrm{~kg}$ of starch/d, with both not differing from 1.5 $\mathrm{kg}$ of starch/d. The same was observed for the intake of
$\mathrm{CP}, \mathrm{NDF}$, digestible NDF, ADF, ADL, and sugar, where the intake of all these nutrients was lower $(P<0.025)$ with infusion of $3.0 \mathrm{~kg}$ of corn starch/d compared with $0.0 \mathrm{~kg}$ of corn starch/d, and with both not differing from infusion of $1.5 \mathrm{~kg}$ of corn starch/d. Abomasal infusion of corn starch increased the DMI of the infusate $(P$ $<0.001)$ due to the design of the infusion treatments. Subsequently, total DMI (DMI TMR + DMI infusate) and the intake of OM and GE were higher $(P<0.016)$ with infusion of $3.0 \mathrm{~kg}$ of corn starch/d compared with $0.0 \mathrm{~kg}$ of corn starch/d, with both not differing from $1.5 \mathrm{~kg}$ of corn starch/d. The intake of starch increased $(P<0.001)$ with each increasing level of abomasal infusion of corn starch. The ATTD of DM, OM and GE decreased $(P<0.001)$ with each increasing level of infused corn starch. The ATTD of CP was lower $(P<$ 0.001 ) for $1.5 \mathrm{~kg}$ and $3.0 \mathrm{~kg}$ of corn starch/d compared with $0.0 \mathrm{~kg}$ of corn $\mathrm{starch} / \mathrm{d}$, with no difference between 1.5 and $3.0 \mathrm{~kg}$ of corn starch/d.

Regardless of the presence of corn starch in the infusion, DMI of the infusate increased $(P<0.001)$ upon abomasal infusion of BHB due to the design of the infusion treatments. Infusion of BHB decreased $(P<$ 0.044) the intake of digestible NDF, ATTD of CP, and ATTD of crude fat compared with no BHB infusion.

\section{Milk Production and Composition}

Milk yield $(P=0.075)$ and milk protein concentration $(P=0.090)$ tended to be affected and feed efficiency ( $\mathrm{kg}$ of fat- and protein-corrected milk $/ \mathrm{kg}$ of total DMI) was affected $(P=0.010)$ by a corn starch $\times$ BHB interaction (Table 4). Abomasal infusion of $3.0 \mathrm{~kg}$ of corn starch/d decreased feed efficiency, but only when BHB was not present. Regardless of BHB infusion, abomasal infusion of corn starch tended to decrease $(P=0.084)$ milk fat concentration and decreased $(P<0.001)$ milk urea concentration. Milk urea concentration was lower with infusion of $3.0 \mathrm{~kg}$ of corn starch/d compared with $0.0 \mathrm{~kg}$ of corn starch/d, with both not differing from $1.5 \mathrm{~kg}$ of corn starch/d. Regardless of the presence of corn starch in the infusion, milk urea concentration decreased $(P=0.007)$ and milk BHB concentration increased $(P<0.001)$ with abomasal infusion of BHB compared with no BHB infusion.

\section{Blood and Plasma Constituents}

Blood partial pressure of $\mathrm{O}_{2}$ and anion gap tended $(P \leq 0.093$; Table 5$)$ to be affected by a corn starch $\times$ $\mathrm{BHB}$ interaction. The results of the anion gap should be interpreted with caution because, as mentioned earlier, this variable was also significantly affected by a carryover effect between periods. Regardless of the 
van Gastelen et al.: HINDGUT AND METABOLIC ACIDOSIS

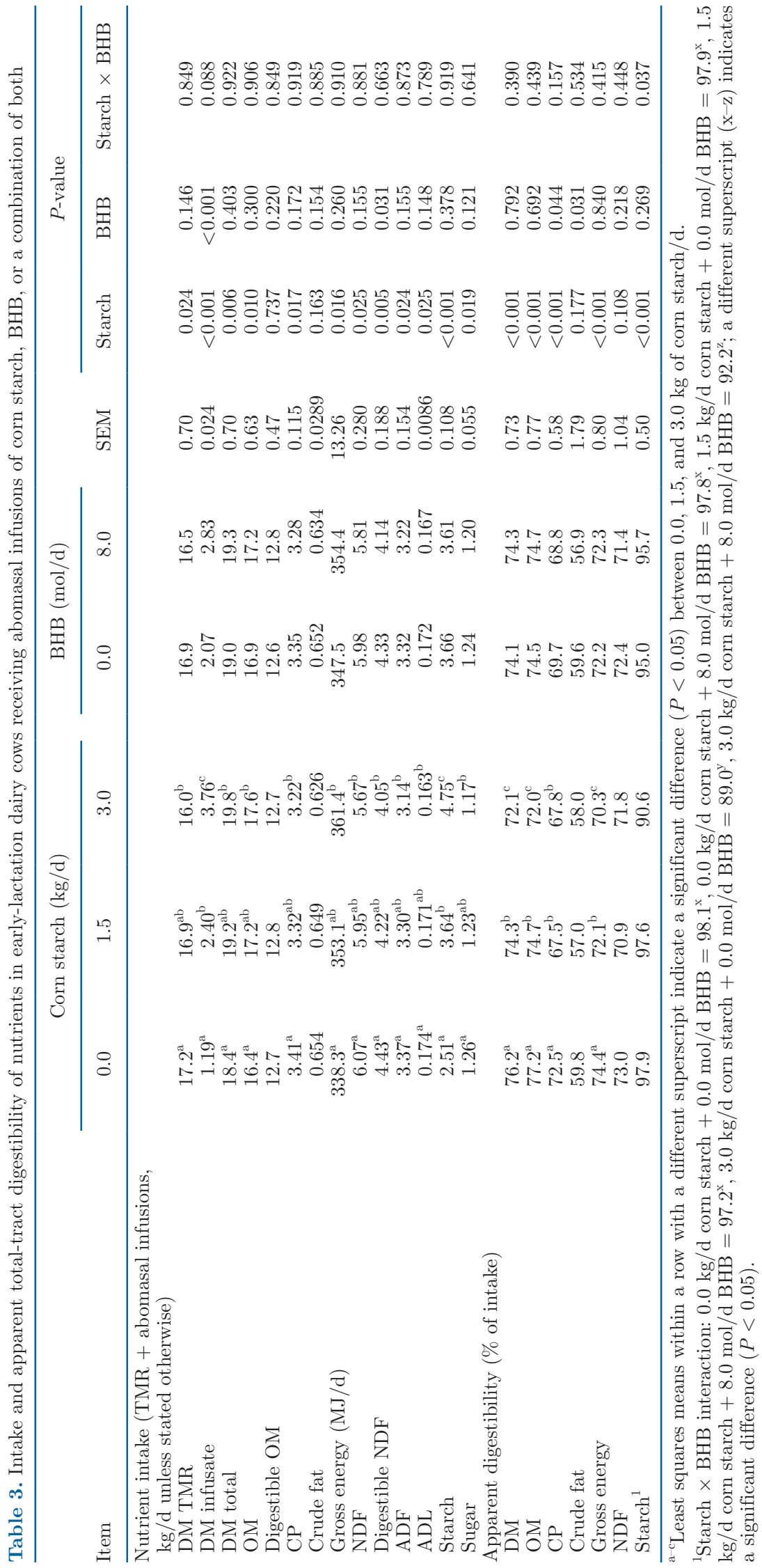




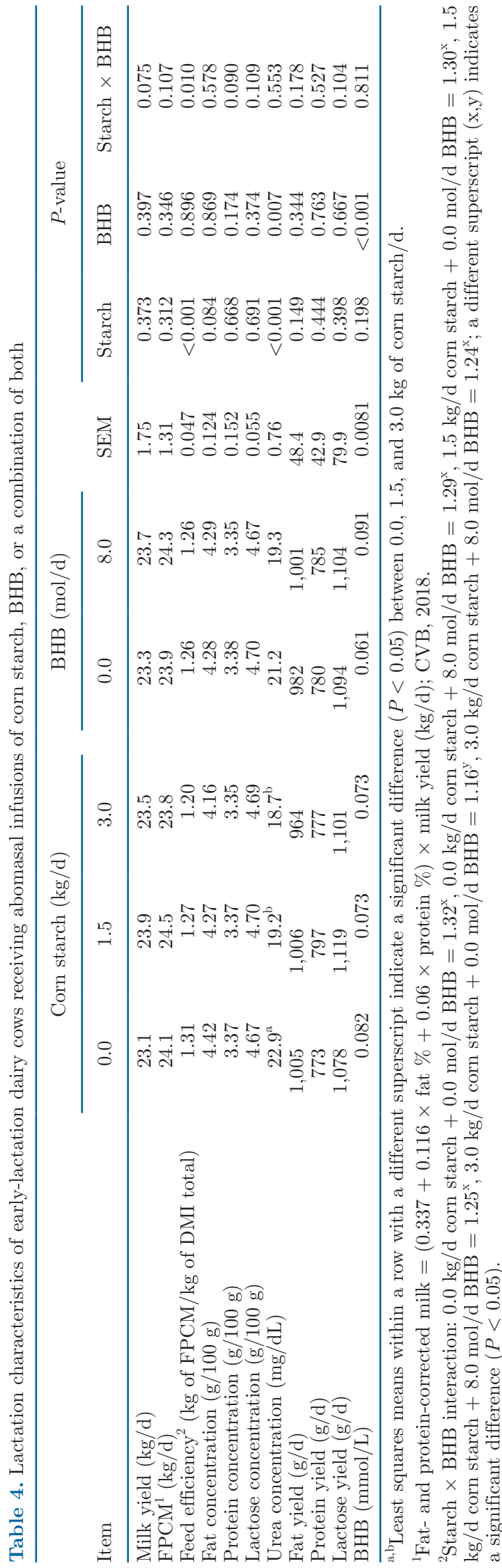

presence of BHB, total $\mathrm{CO}_{2}$ tended to decrease $(P=$ $0.072)$ and ionized calcium tended to increase $(P=$ 0.074) upon infusion of corn starch. Blood $\mathrm{pH}$ and $\mathrm{HCO}_{3}$ were lower $(P \leq 0.048)$ with infusion of $3.0 \mathrm{~kg}$ of corn starch/d compared with $0.0 \mathrm{~kg}$ of corn starch/d, with both not differing from $1.5 \mathrm{~kg}$ of corn starch/d. Blood base excess was lower $(P=0.006)$ for $3.0 \mathrm{~kg}$ of corn starch/d compared with 0.0 and $1.5 \mathrm{~kg}$ of corn starch/d, with no difference between the latter 2 levels of corn starch. Blood urea $\mathrm{N}$ was lower $(P<0.001)$ for 1.5 and $3.0 \mathrm{~kg}$ of corn starch/d compared with $0.0 \mathrm{~kg}$ of corn starch/d, with no difference between the former 2 levels of corn starch. Blood chloride concentration was higher $(P=0.006)$ with infusion of $3.0 \mathrm{~kg}$ of corn starch/d compared with $0.0 \mathrm{~kg}$ of corn $\mathrm{starch} / \mathrm{d}$, with both not differing from $1.5 \mathrm{~kg}$ of corn starch/d.

Regardless of the presence of corn starch in the infusion, BHB infusion decreased $(P \leq 0.031)$ blood base excess; blood concentration of $\mathrm{HCO}_{3}$, total $\mathrm{CO}_{2}$, and glucose; and plasma concentration of insulin, compared with no BHB infusion. Infusion of BHB increased $(P \leq$ 0.045) blood anion gap, and plasma BHB and cobalt concentration compared with no BHB infusion. Also here, the results of the anion gap should be interpreted with caution because this variable was also significantly affected by a carryover effect between periods.

\section{Energy and Nitrogen Balance}

None of the variables associated with energy and $\mathrm{N}$ balance were affected by a corn starch $\times$ BHB interaction (Table 6). Regardless of the presence of BHB, metabolic $\mathrm{BW}$ tended to decrease in response to corn starch infusion. The respiratory quotient was higher $(P<0.001)$ with infusion of 1.5 and $3.0 \mathrm{~kg}$ of corn starch/d compared with $0.0 \mathrm{~kg}$ of corn starch/d, with no difference between the former 2 levels of corn starch. Intake of GE (GEI) was higher $(P=0.013)$ with infusion of $3.0 \mathrm{~kg}$ of corn starch/d compared with $0.0 \mathrm{~kg}$ of corn starch/d, with both not differing from $1.5 \mathrm{~kg}$ of corn starch/d. Energy excreted in manure increased $(P<0.001)$ with every increasing level of infused corn starch. The ratio between metabolizable energy intake (MEI) and GEI was lower $(P<0.001)$ for $3.0 \mathrm{~kg}$ of corn starch/d compared with 0.0 and $1.5 \mathrm{~kg}$ of corn starch/d, with no difference between the latter 2 levels of corn starch.

Nitrogen intake was lower with infusion of $3.0 \mathrm{~kg}$ of corn starch/d compared with $0.0 \mathrm{~kg}$ of corn starch/d, with both not differing from $1.5 \mathrm{~kg}$ of corn starch/d. Nitrogen excreted via urine and $\mathrm{N}$ trapped in condensed water and acid were higher $(P \leq 0.007)$ for $0.0 \mathrm{~kg}$ of corn starch/d compared with 1.5 and $3.0 \mathrm{~kg}$ of corn starch/d, with no difference between the latter 2 levels 
van Gastelen et al.: HINDGUT AND METABOLIC ACIDOSIS

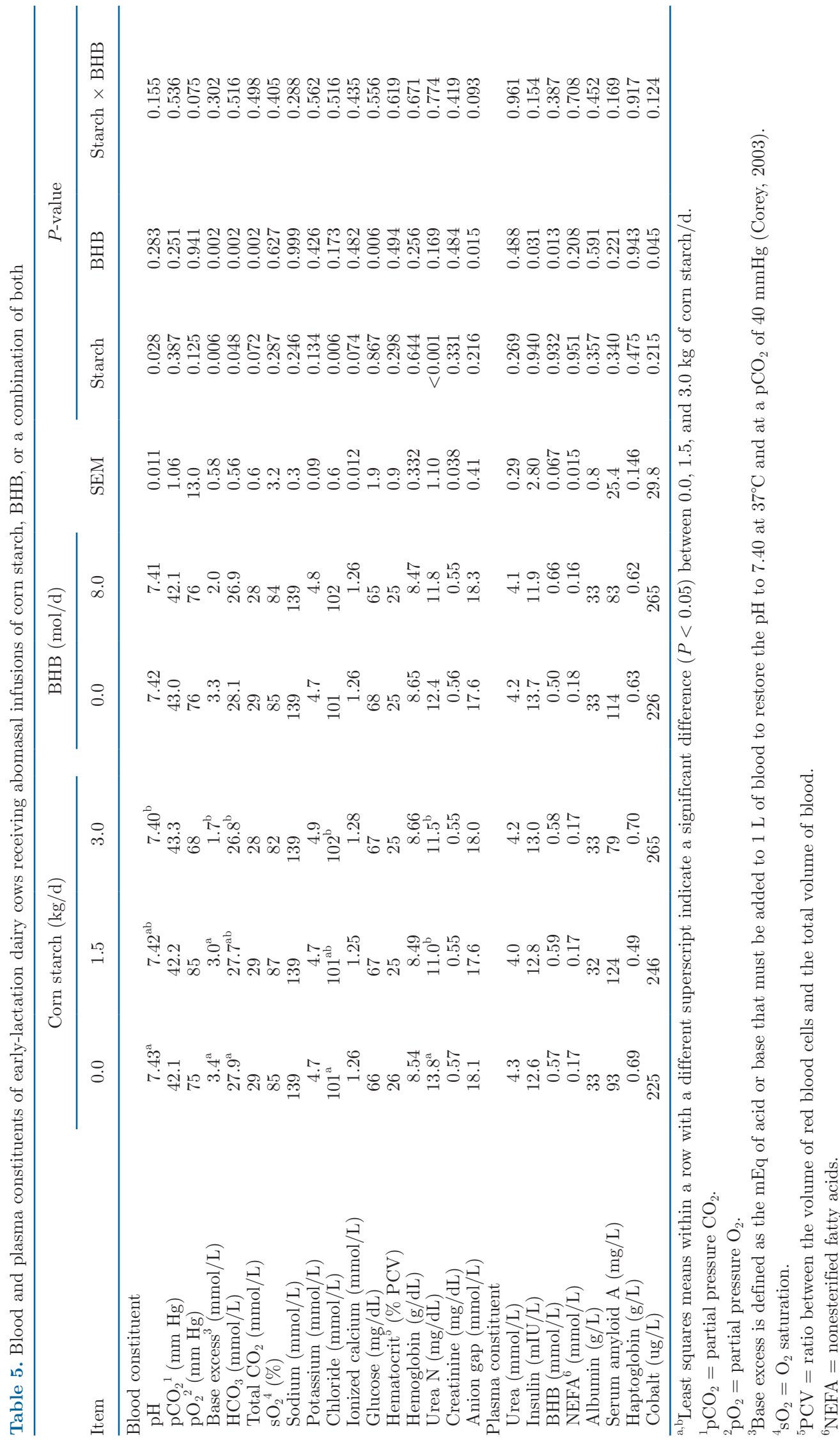


van Gastelen et al.: HINDGUT AND METABOLIC ACIDOSIS

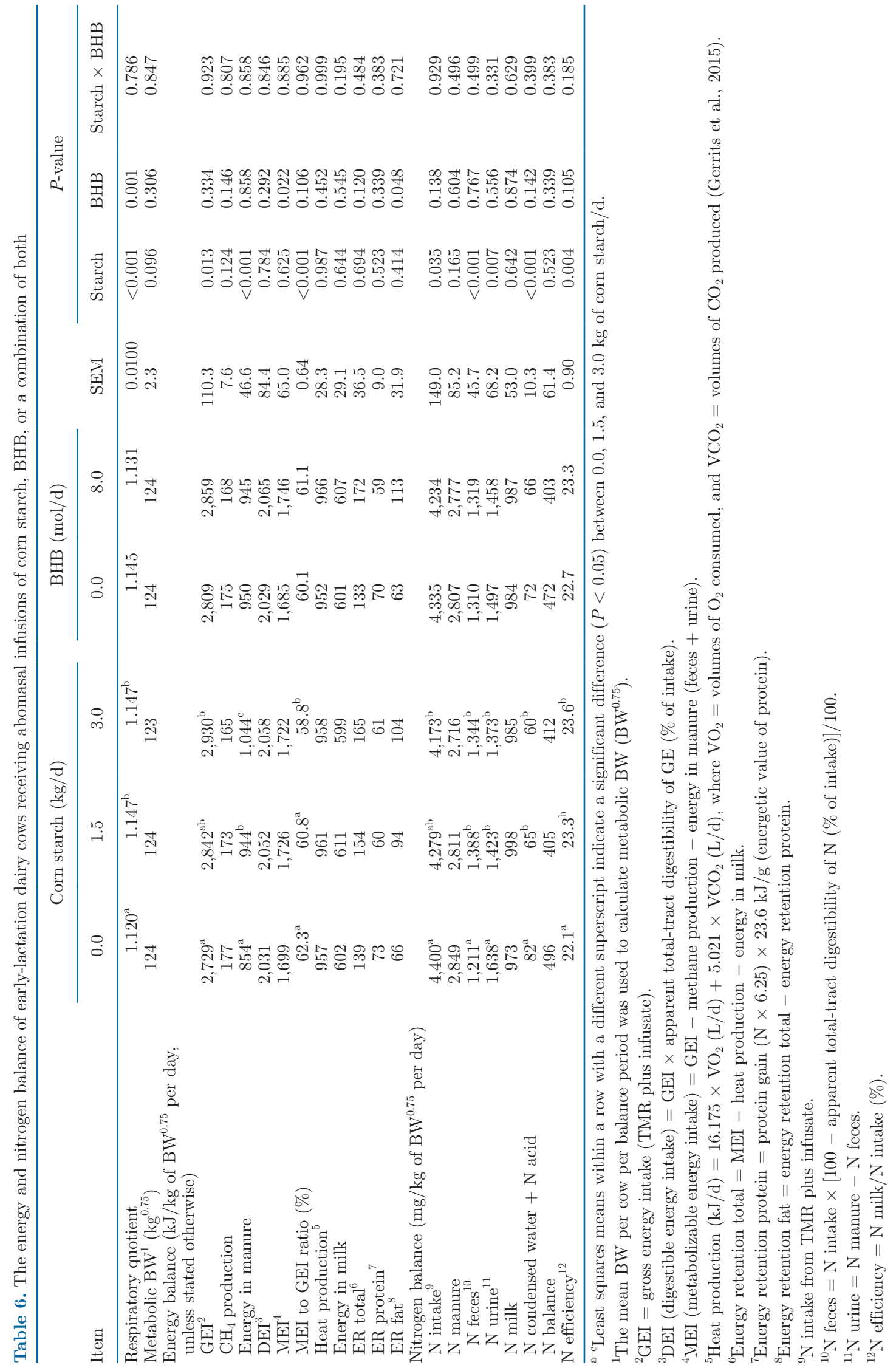


of corn starch. Infusion of corn starch increased $(P \leq$ $0.004) \mathrm{N}$ excreted via feces and $\mathrm{N}$ efficiency, where both were lower with $0.0 \mathrm{~kg}$ of corn $\mathrm{starch} / \mathrm{d}$ compared with 1.5 and $3.0 \mathrm{~kg}$ of corn starch/d, with no difference between the latter 2 levels of corn starch.

Regardless of the presence of corn starch, infusion of BHB decreased $(P=0.001)$ the respiratory quotient, but increased $(P \leq 0.048)$ MEI and energy retained as fat compared with no BHB infusion. Abomasal infusion of BHB did not affect any of the $\mathrm{N}$ balance variables.

\section{Ruminal Fluid, Feces, and Urine}

Ruminal butyrate proportions, fecal total VFA concentration, and fecal valerate proportions were affected $(P \leq 0.031)$ by a corn starch $\times$ BHB interaction (Table 7). Despite the significant corn starch $\times$ BHB interaction for ruminal butyrate, no significant differences were found between treatment means using the Tukey-Kramer method. Infusion of BHB decreased the fecal total VFA concentration, but only when combined with $3.0 \mathrm{~kg}$ of corn starch/d. Fecal valerate proportions decreased with every increasing level of infused corn starch, but only in the absence of BHB. With BHB infusion, the fecal valerate proportion was higher for $0.0 \mathrm{~kg}$ of corn starch/d compared with 1.5 and $3.0 \mathrm{~kg}$ of corn starch/d, with no difference between the latter 2 levels of corn starch.

Regardless of the presence of BHB in the infusion, starch infusion did not affect any of the ruminal fermentation variables. Fecal consistency score was higher $(P=0.050)$ for $3.0 \mathrm{~kg}$ of corn starch $/ \mathrm{d}$ compared with $0.0 \mathrm{~kg}$ of corn starch/d, with both levels of corn starch not differing from $1.5 \mathrm{~kg}$ of corn starch/d. Fecal $\mathrm{pH}$ and fecal isovalerate proportion decreased $(P<0.001)$ with every increasing level of corn starch infused. Fecal propionate proportion and urine $\mathrm{pH}$ were lower $(P<$ 0.001 ) with $3.0 \mathrm{~kg}$ of corn starch/d compared with 0.0 and $1.5 \mathrm{~kg}$ of corn starch/d, with no difference between the latter 2 levels of corn starch. Infusion of corn starch also decreased $(P<0.001)$ fecal isobutyrate proportions, which were lower with 1.5 and $3.0 \mathrm{~kg}$ of corn starch/d compared with $0.0 \mathrm{~kg}$ of corn starch/d, with no difference between the former 2 levels of corn starch. Fecal butyrate proportions increased $(P<0.001)$ with every increasing level of infused corn starch. The acetate to propionate ratio in feces increased $(P<0.001)$ with infusion of $3.0 \mathrm{~kg}$ of corn starch/d compared with 0.0 and $1.5 \mathrm{~kg}$ of corn starch/d, with no difference between the latter 2 levels of corn starch.

Regardless of the presence of corn starch, fecal acetate proportion $(P=0.069)$ and urine $\mathrm{pH}(P=0.057)$ tended to decrease with abomasal infusion of BHB. Fecal butyrate proportions were higher $(P=0.009)$ when BHB was present in the infusion compared with no BHB.

\section{DISCUSSION}

The aim of this study was to induce hindgut and metabolic acidosis via abomasal infusion of corn starch and $\mathrm{BHB}$, respectively, and to determine the effects of these physiological states in early-lactation cows. Ruminal fermentation characteristics were largely unaffected by either starch or BHB infusion, suggesting that there was no appreciable back-flow of infusates into the rumen. Therefore, our aim to induce acidosis only posterior to the rumen was achieved.

\section{Establishment of Hindgut Acidosis}

Currently, there is no clear fecal $\mathrm{pH}$ threshold defined for hindgut acidosis, but fecal $\mathrm{pH}$ was previously reported to be 6.30 ( $\mathrm{Li}$ et al., 2012) to 6.49 (Danscher et al., 2015) for control-fed animals. Considering these values as a threshold in combination with the observed fecal $\mathrm{pH}$, hindgut acidosis was achieved upon infusion of 1.5 and $3.0 \mathrm{~kg} / \mathrm{d}$ starch, and became more severe with a higher corn starch level. Van Gastelen et al. (2021) reported a fecal $\mathrm{pH}$ of 6.86 without abomasal infusion of ground corn and a fecal pH of 6.00 when 3.0 $\mathrm{kg}$ of ground corn $/ \mathrm{d}$ (equals $\sim 1.5 \mathrm{~kg}$ of $\mathrm{starch} / \mathrm{d}$, when corrected for DM and starch content) was infused into the abomasum. This is in agreement with the results of the present study, where infusion of $1.5 \mathrm{~kg}$ of corn starch/d resulted in an average fecal $\mathrm{pH}$ of 6.00 and infusion of $3 \mathrm{~kg}$ of corn starch/d decreased fecal $\mathrm{pH}$ even further.

The decrease in fecal $\mathrm{pH}$ with 1.5 and $3.0 \mathrm{~kg}$ of corn starch/d suggests that part of the infused corn starch escaped intestinal digestion and was fermented in the hindgut (Reynolds et al., 2001). This is supported by the decrease in ATTD of CP, likely as a result of increased microbial protein synthesis, and by the increase in respiratory quotient, likely as a result of anaerobic fermentation of dietary carbohydrates (Gerrits et al., 2015). Contrary to van Gastelen et al. (2021), we did not observe an increase in total VFA concentration in feces upon abomasal infusion of corn starch. This lack of effect on fecal total VFA concentrations combined with decreased fecal $\mathrm{pH}$ suggests that the buffering capacity of the large intestine may have changed with abomasal infusion of corn starch. 
van Gastelen et al.: HINDGUT AND METABOLIC ACIDOSIS

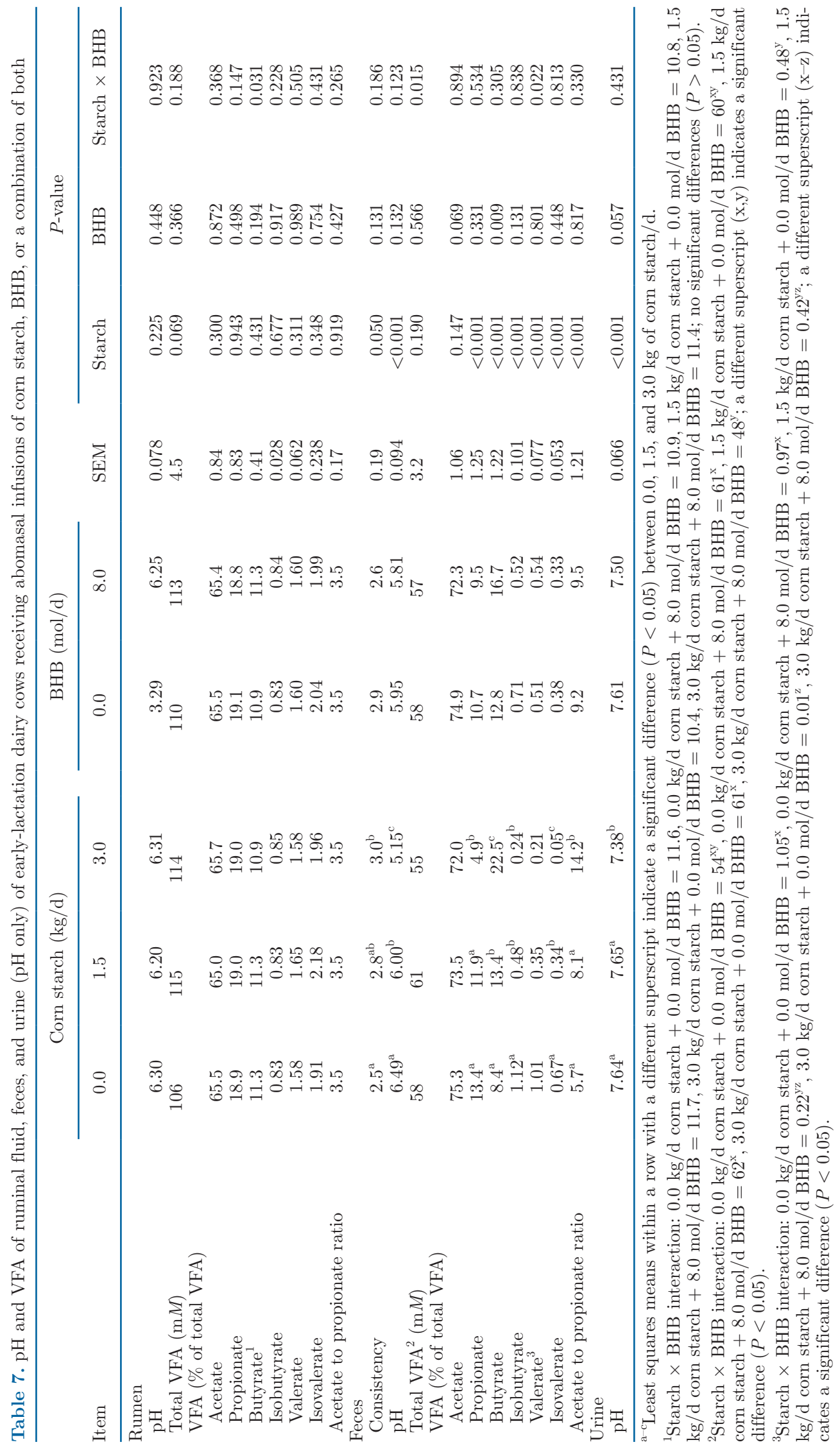


Infusion of corn starch in the abomasum appeared to disturb the acid-base status of the dairy cows, likely related to increased VFA absorption from the hindgut during corn starch infusion. In the rumen, absorption of VFA is suspected to be primarily regulated by the anion exchange pathway, where VFA are absorbed in exchange for the secretion of $\mathrm{HCO}_{3}$ (Aschenbach et al., 2009). An acid load in the rumen depleted $\mathrm{HCO}_{3}$ from the blood and decreased blood $\mathrm{pH}$ in beef steers (Brown et al., 2000). This mechanism is likely valid for the hindgut as well, especially when excessive fermentation takes place.

The increase in the molar proportion of fecal butyrate upon abomasal infusion of corn starch is consistent with what has been observed in monogastric animals during hindgut fermentation of slowly fermentable starch (Lv et al., 2006), as well as in dairy cattle fed a high concentrate diet (Mao et al., 2012). It has been suggested that elevated colonic butyrate levels may support a healthy gut environment because of the use of butyrate by the intestinal epithelium as an energy source (Brouns et al., 2002). Increased fecal concentration of butyrate, assuming absorption of butyrate has not changed largely, is an indication of increased butyrate production in the hindgut. Thus, more butyrate may have been available for hindgut epithelia, and could have provided a supportive effect on epithelial function in the hindgut.

Based on the data from the present study and that of van Gastelen et al. (2021), we determined the relation between fecal $\mathrm{pH}$ and the amount of corn starch infused into the abomasum (i.e., on individual cow level, not treatment means). The Pearson correlation between fecal $\mathrm{pH}$ and the amount of corn starch abomasally infused was negative $(P<0.001, \mathrm{r}=-0.84)$, where fecal $\mathrm{pH}=6.74( \pm 0.063)-0.59( \pm 0.047) \times \mathrm{kg}$ of corn starch abomasally infused. Assuming that a fecal $\mathrm{pH}$ of 6.00 (i.e., lower threshold reported by Plaizier et al., 2018) indicates hindgut acidosis, hindgut acidosis would be induced as soon as $1.25 \mathrm{~kg}$ of extra corn starch/d enters the abomasum, irrespective of the source of corn starch. Based on the variation in ruminal starch digestion in ruminants (Mills et al., 1999; Allen, 2000; Moharrery et al., 2014), we assume that $60 \%$ (i.e., common for corn) to $80 \%$ of starch intake is fermented in the rumen. Considering this alongside the above-described equation, daily total starch intake would have to reach at least 3.1 to $6.3 \mathrm{~kg} / \mathrm{d}$ before hindgut acidosis may possibly be induced. The average DMI of the present study and that of van Gastelen et al. (2021) was 16.7 $\mathrm{kg} / \mathrm{d}$. Hence, the intake of 3.1 and $6.3 \mathrm{~kg}$ of $\mathrm{starch} / \mathrm{d}$ would be achieved at a dietary starch content of 186 to $371 \mathrm{~g} / \mathrm{kg}$ of DM, respectively. These levels, particularly the lower dietary starch content, is easily achieved in practice under many farming conditions.

\section{Effects of Abomasal Corn Starch Infusion and Associated Hindgut Acidosis}

The model used to induce hindgut acidosis in the present study differs from some studies where hindgut acidosis was induced. Li et al. (2012) and Plaizier et al. (2017) induced hindgut acidosis via a grain-based SARA challenge. In this model, feeding large amounts of grain is combined with poor rumen mat function associated with SARA conditions. This generally leads to larger amounts of fermentable substrates that bypass rumen fermentation. If these substrates are not digested in the small intestine, these will be fermented in the hindgut (Plaizier et al., 2018). In contrast, the abomasal infusion model used in the present study induced hindgut acidosis but did not affect ruminal conditions. Hence, differences in the models applied to induce hindgut acidosis may lead to differences in results (i.e., the effects of hindgut acidosis) across studies.

Nutrient Intake and Digestibility. We observed a depressed voluntary TMR DMI with abomasal infusion of $3.0 \mathrm{~kg}$ of corn starch/d, but not with the abomasal infusion of $1.5 \mathrm{~kg}$ of corn starch/d. This is in agreement with van Gastelen et al. (2021), who did not observe a decreased voluntary DMI when $3.0 \mathrm{~kg}$ of ground corn/d (equal to $\sim 1.5 \mathrm{~kg}$ of $\mathrm{starch} / \mathrm{d}$ ) was infused in the abomasum. On the contrary though, both Reynolds et al. (1998) and Knowlton et al. (1998) observed a decreased voluntary DMI when $1.2 \mathrm{~kg}$ of wheat starch $/ \mathrm{d}$ and $1.5 \mathrm{~kg}$ of hydrolyzed starch/d was infused, respectively.

In the present study, ATTD of nutrients was determined by including $\mathrm{TiO}_{2}$ in the concentrate as an external marker and collecting fecal samples twice daily during the infusion period. Morris et al. (2018) stated that sampling feces twice daily (as we have done) might result in different fecal marker and nutrient concentrations compared with sampling feces 12 times daily. However, cows were fed only once daily in the study of Morris et al. (2018), whereas the cows in the present study were fed according to a steady-state pattern during the period of sampling. Steady-state feeding will reduce diurnal variation in fecal marker and nutrient concentrations (Owens and Hanson, 1992). Furthermore, Titgemeyer et al. (2001) showed that $\mathrm{TiO}_{2}$ recoveries that did not differ from $100 \%$ when cattle were adapted to marker administration for 17 to $21 \mathrm{~d}$ before measurement of nutrient ATTD. In the present study, cows were adapted to marker administration for at least $21 \mathrm{~d}$. Hence, we consider the duration the duration of marker administration as well as the frequency of fecal sampling (in combination with steady-state feeding) sufficient to draw conclusions from the results concerning ATTD of nutrients. 
The decreased ATTD of most nutrients upon abomasal infusion of corn starch is generally in agreement with van Gastelen et al. (2021) but contrary to Knowlton et al. (1998) and Reynolds et al. (2001). Van Gastelen et al. (2021) proposed that overall fermentation and absorption are lower for postruminally infused nutrients than for nutrients entering the rumen. By avoiding ruminal fermentation, it is likely that starch, and subsequently, DM, OM, and GE (i.e., because starch contributes to these fractions), were digested to a lesser extent. In contrast, nutrients that originate entirely from the TMR fed (i.e., fat and NDF) undergo rumen fermentation, explaining the unaffected ATTD of these nutrients upon abomasal infusion of corn starch. Decreased ATTD of CP was likely the result of increased microbial protein synthesis upon fermentation of the infused corn starch, and was also observed by Gressley and Armentano (2007) and Gressley et al. (2011) in response to increased starch supply. If this microbial protein remains undigested in the hindgut, it is excreted as microbial $\mathrm{N}$ and thereby decreases ATTD of $\mathrm{N}$ (Owens et al., 1986). As $\mathrm{N}$ contributes to the DM, $\mathrm{OM}$, and GE fraction, decreased ATTD of N likely also results in decreased ATTD of DM, OM, and GE.

Energy Partitioning. The decreased ATTD of GE, as discussed above, in combination with increased GEI, resulted in increased energy excreted via manure upon abomasal infusion of corn starch. When corn starch is digested or fermented in the hindgut, increased MEI is expected from greater glucose and VFA absorption (Reynolds, 2006). In the present study, however, both MEI and blood glucose concentration were unaffected by abomasal infusion of corn starch, contrary to van Gastelen et al. (2021) but in line with Knowlton et al. (1998). The lack of effect on blood glucose concentration, despite the large quantities of starch that were infused, can be explained by greater utilization of arterial glucose by tissues of the portal-drained viscera relative to absorbed glucose (Reynolds et al., 1998), oxidation of luminal glucose by enterocytes (Knowlton et al., 1998), decreased hepatic gluconeogenesis in response to the increased glucose absorption (Clark et al., 1977), or a combination of these mechanisms.

Milk yield is largely regulated through the osmotic properties of lactose, where synthesis of lactose requires the transport of glucose from blood into the cytosol of mammary epithelial cells (Cant et al., 2002). The unaffected milk yield, milk lactose concentration, and lactose yield in response to abomasal corn starch infusion, are therefore in line with the increased energy excretion in manure and the unaffected blood glucose concentrations. Milk fat concentration tended to decrease when corn starch was infused into the abomasum, which is contrary to Reynolds et al. (2001), Rius et al. (2010), and van Gastelen et al. (2021), but similar to Knowlton et al. (1998). When elevated in circulation, glucose promotes insulin secretion (Bauman and Griinari, 2001). Insulin stimulates the uptake of lipogenic precursors into adipose tissue and decreases lipolysis, resulting in a reduction of circulating fatty acids for milk fat synthesis (Bauman and Griinari, 2001). Although energy retained as fat, blood glucose concentration, and concentrations of insulin, NEFA, and BHB in plasma were not affected by abomasal infusion of corn starch in the present study, the tendency for a decreased milk fat concentration suggests a reduced availability of longchain fatty acids for milk lipid synthesis during infusion of corn starch.

Nitrogen Partitioning. The transfer efficiency of feed $\mathrm{N}$ into milk $\mathrm{N}$ may increase when glucogenic energy supply to the animal is increased. This is because of reduced catabolism of AA for gluconeogenesis, leaving more available for milk protein synthesis. Contrary to the findings of Rius et al. (2010) and van Gastelen et al. (2021), milk protein content or yield did not increase in response to corn starch infusion in the present study. These results are, however, in line with the lack of effect of starch infusion on blood glucose or plasma insulin concentrations and in agreement with Knowlton et al. (1998) and Reynolds et al. (2001). The increased $\mathrm{N}$ efficiency observed with corn starch infusion was due to lower $\mathrm{N}$ intake as a result of a lower DMI of the TMR combined with unaffected milk $\mathrm{N}$ secretion.

We observed a clear shift in $\mathrm{N}$ excretion from urinary $\mathrm{N}$ to fecal $\mathrm{N}$ upon abomasal infusion of corn starch, similar to Reynolds et al. (2001) and van Gastelen et al. (2021). This is likely related to increased microbial protein synthesis in the hindgut arising from fermentation of the infused corn starch in the large intestine. The $\mathrm{N}$ source for this microbial protein may have partly been derived from blood next to $\mathrm{N}$ sources in the digesta. Thus, the decreased urinary $\mathrm{N}$ is in line with the decreased blood urea $\mathrm{N}$ concentration and decreased milk urea concentration upon abomasal infusion of corn starch.

Immune Response. Similar to van Gastelen et al. (2021), the lack of effect of abomasally infused corn starch on the plasma concentration of acute phase proteins suggests that hindgut fermentation of corn starch did not result in a systemic inflammatory response detectable by these plasma markers. An alteration in the condition of intercellular tight junctions (e.g., structural damage in response to acidic conditions), can result in increased permeability of the intestine to large molecules. Damaged tight junctions become leaky, allowing pathogens and toxins to enter the bloodstream (Kameda et al., 1968). Intestinal permeability measured by the appearance of $\mathrm{Co}$ (of the indigestible marker Co- 
EDTA) in blood appeared to be unaffected, suggesting that abomasal infusion of up to $3.0 \mathrm{~kg}$ of corn starch/d did not result in a leaky gut.

\section{Establishment of Metabolic Acidosis}

Blood $\mathrm{pH}$ was not affected by abomasal infusion of $\mathrm{BHB}$ and was within the normal physiological range for BHB and non-BHB treatments (i.e., between 7.38 and $7.43 \mathrm{pH}$ units; Indrova et al., 2017). This suggests that daily infusion of $8 \mathrm{~mol} \mathrm{BHB}$ did not result in metabolic acidosis. However, in clinically healthy cows, acid-base disturbances are compensated by various regulatory mechanisms (Gärtner et al., 2019). Respiratory compensation is commonly characterized during suspected acid-base disturbances by a reduced partial pressure of $\mathrm{CO}_{2}$ (Gant et al., 1998). Respiratory compensation, however, is of minor importance in dairy cows because of their relatively small lung capacity (Enemark et al., 2002), so it follows that $\mathrm{pCO}_{2}$ was maintained within normal range (i.e., between 35 and $45 \mathrm{mmHg}$; Constable, 1999) during abomasal infusion of BHB in the present study. When a respiratory response is not present, total $\mathrm{CO}_{2}, \mathrm{HCO}_{3}$, and base excess can be used as indicators for an acid-base disturbance (Constable, 1999). Although these 3 variables decreased upon abomasal infusion of BHB, they remained within their normal physiological ranges (e.g., between -0.5 and 4.5 $\mathrm{mmol} / \mathrm{L}$ for base excess; Indrova et al., 2017). These results, combined with a tendency for a decreased urinary $\mathrm{pH}$, suggest that a compensated metabolic acidosis was induced via abomasal BHB infusion. This is characterized by an acid-base disturbance but un unaffected blood pH (Vagnoni and Oetzel, 1998; Zimpel et al., 2018).

Concentration greater than $1.2 \mathrm{mmol} \mathrm{BHB} / \mathrm{L}$ of blood (Enjalbert et al., 2001) and $0.2 \mathrm{mmol} \mathrm{BHB} / \mathrm{L}$ of milk (Geishauser et al., 2000) have been proposed as critical threshold values indicating subclinical ketosis. The observed concentrations of BHB in milk and plasma were well below these thresholds, irrespective of the infusion treatment. This suggests that $8 \mathrm{~mol} \mathrm{BHB} / \mathrm{d}$ infused into the abomasum was not sufficient to induce a state resembling subclinical ketosis or ketoacidosis (i.e., accumulation of ketone bodies causing metabolic acidosis; Ewaschuk et al., 2002). We based our BHB dose on the assumption that, on average, $28 \mathrm{~kg}$ of body fat would be mobilized over a period of 8 wk (i.e., $500 \mathrm{~g}$ of body fat/d; Tamminga et al., 1997; van Knegsel et al. 2007a). Mobilization of $500 \mathrm{~g}$ of body fat/d equals some $1.6 \mathrm{~mol} \mathrm{C18}$ fatty acids/d, considering the molar weight of triglycerides (i.e., $946 \mathrm{~g}$ if consisting of glycerol and 3 fatty acids with 18C). We assumed that $100 \%$ of these C18 fatty acids would be converted into BHB as a C4 fatty acid (i.e., $1 \mathrm{~mol}$ C18 fatty acids delivering $4 \mathrm{~mol}$ BHB), and that the capacity of the liver to oxidize NEFA is exceeded and all NEFA are converted into ketone bodies. Hence, $6.3 \mathrm{~mol} \mathrm{BHB/d}$ would be produced by the liver on average for the first 8 wk of lactation. In the current study, we realized an infused supply of 7.7 to $8.0 \mathrm{~mol} \mathrm{BHB} / \mathrm{d}$, which is about $25 \%$ more than this estimated level of endogenous BHB production. This dose was apparently not sufficient to induce a subclinical ketosis or ketoacidosis. Herrick et al. (2018) stated that ketosis-indicating threshold concentrations of BHB in milk or plasma are based on elevated levels of endogenously produced ketones arising from liver dysfunction and excessive body fat mobilization. There was no evidence in the current study that these conditions were occurring upon BHB infusion (i.e., increased energy retention in body fat, no effect on plasma NEFA concentrations or TMR DMI). Therefore, it is logical that exogenously supplied BHB produced a metabolic response characterized as a compensated metabolic acidosis rather than a classical ketoacidosis.

\section{Effects of Abomasal BHB Infusion and Associated Compensated Metabolic Acidosis}

Nutrient Intake and Digestibility. Ketosis is generally associated with reduced feed intake (e.g., Benedet et al., 2019). This is likely related to the stimulation of oxidative metabolism and signals of energy status and satiety in the brain by ketones (Laeger et al., 2010) as well as to changes in acid-base balance (Zimpel et al., 2018). Abomasal infusion of BHB did not affect voluntary DMI of the TMR in the current study, likely because only a compensated metabolic acidosis was observed and because plasma BHB concentration, although elevated, may not have reached critical levels affecting satiety. In agreement, Zarrin et al. (2013, 2014) found no reduction in DMI of dairy cows when BHB was intravenously infused for 48 and $56 \mathrm{~h}$, respectively. The decreased digestible NDF intake following abomasal infusion of BHB appears to be the result of a numerical decrease in TMR DMI and ATTD of NDF. The decrease in ATTD of CP and fat might be related to the increased intestinal permeability (suggested by the increased Co concentration in blood) upon abomasal infusion of BHB. An increased permeability may negatively affect hindgut fermentation and the stability of the intestinal microbiota. Taking this into account, it is unclear why the ATTD of starch increased with abomasal infusion of BHB when combined with $3.0 \mathrm{~kg}$ of corn starch/d, but not when combined with the lower infusion level of corn starch.

Energy Partitioning. Abomasal infusion of BHB decreased blood glucose and plasma insulin concentra- 
tions. This suggests that insulin did not play a role in the inhibiting effect of BHB on glucose concentrations, which is in agreement with studies in sheep (Schlumbohm and Harmeyer 2003) and dairy cows (Zarrin et al., 2013). Alongside insulin, gluconeogenesis is also hormonally regulated by glucagon (Zarrin et al., 2013). Glucagon increases plasma glucose concentration through stimulation of gluconeogenesis and glycogenolysis (Aronoff et al., 2004). Ketone bodies and NEFA can suppress glucagon secretion (Gerich et al., 1974), and Zarrin et al. (2013) reported decreased glucagon concentrations when BHB was intravenously infused in dairy cattle. Although not measured in the current study, glucagon secretion may have been depressed by the elevated plasma BHB concentration upon abomasal infusion of BHB, which may have resulted in less stimulation of gluconeogenesis or glycogenolysis and subsequently reduced blood glucose concentrations.

The effects of elevated plasma BHB concentrations on milk yield in literature are controversial. Several studies observed a decrease of daily milk production between $1 \%$ and $18 \%$ (e.g., Duffield et al., 2009; McArt et al., 2012), whereas others reported an increase of daily milk yield between $5 \%$ and $11 \%$ (e.g., Vanholder et al., 2015; Ruoff et al., 2017; reviewed by Benedet et al., 2019) in cows with an elevated plasma BHB concentration $(>1.2 \mathrm{mmol} / \mathrm{L})$. Ketone bodies can have a glucose-sparing effect in tissues where ketone bodies can be used as an energy source (Zarrin et al., 2013), but glucose is required as a unique source for mammary lactose synthesis (Zarrin et al., 2014). Despite the decreased blood glucose concentrations observed in the present study, milk yield and lactose yield were not affected by abomasal BHB infusion. This is in agreement with Zarrin et al. (2013; only milk yield reported) as well as Herrick et al. (2018). As demonstrated by Mebane and Madison (1962) and Madison et al. (1964), if the increased plasma $\mathrm{BHB}$ concentration in response to BHB infusion inhibited nonmammary peripheral glucose utilization, sufficient glucose may have been available to support milk production in the current study.

It was expected that abomasal infusion of $\mathrm{BHB}$ would result in an increased milk fat concentration, because BHB can be used as precursor for milk fat synthesis (Bauman and Griinari, 2003), and because increased milk fat concentrations are often observed in ketotic cows (e.g., Duffield et al., 2009; Vanholder et al., 2015; Benedet et al., 2019). However, an increase in milk fat concentration was not observed in the present study, perhaps because the increase in circulating BHB concentration was below threshold levels characteristic of ketotic dairy cows.

We observed an increase in energy retained as body fat in the present study upon abomasal infusion of BHB, suggesting that more body fat was accreted with BHB infusion. This may simply be due to the numerically increased GEI and decreased methane production upon BHB infusion, resulting in a significantly increased MEI. Despite increase MEI, milk energy output was unaffected by BHB infusion, leading to more energy being available for body accretion.

Nitrogen Partitioning. Abomasal BHB infusion had minimal effects on $\mathrm{N}$ partitioning. Interestingly, milk urea concentration decreased in response to BHB infusion. This was also observed by Santschi et al. (2016), where milk urea N concentration was lower for ketotic cows compared with nonketotic cows, and this response was assigned to a lower protein intake for the cows with ketosis. In the present study, $\mathrm{N}$ intake decreased numerically and ATTD of N decreased significantly upon abomasal infusion of BHB. Hence, it is likely that less $\mathrm{N}$ was absorbed from the gastrointestinal tract, resulting in a smaller surplus (indicated as urea in milk or blood).

Immune Response. The increased molar proportion of fecal butyrate upon BHB infusion might be related to the observed increased intestinal permeability, where elevated colonic butyrate levels are thought to have the ability to support a healthy gut environment (Brouns et al., 2002). Assuming that starch fermentation in the hindgut results in increased levels of butyrate (e.g., Mao et al., 2012), BHB infusion may also have caused a shift from starch digestion in small intestines to starch fermentation in hindgut.

Increased intestinal permeability (suggested by the increased Co concentration in blood) appears not to be related to the potential hyperosmolality that could have been caused by infusion of BHB as a ketone salt (Kameda et al., 1968). This is because the non-BHB treatments were formulated to contain the same amount of Na compared with the BHB treatments (Table 2). Although, increased permeability does appear to be attributable to BHB, it is unclear why the epithelium of the large intestine became more permeable or susceptible to damage upon BHB infusion.

\section{CONCLUSIONS}

Fecal $\mathrm{pH}$ decreased with each level of corn starch infused into the abomasum ( $\mathrm{pH}$ of $6.49,6.00$, and 5.15 with $0.0,1.5$, and $3.0 \mathrm{~kg}$ of corn starch infused/d, respectively), suggesting hindgut acidosis was induced when corn starch was abomasally infused. Abomasal infusion of BHB resulted in a compensated metabolic acidosis, which was characterized by a disturbance of the acid-base status (i.e., decreased blood total $\mathrm{CO}_{2}$, $\mathrm{HCO}_{3}$, and base excess, and trend for decreased urinary $\mathrm{pH}$ ), whereas blood $\mathrm{pH}$ remained within a physiologi- 
cally normal range. Overall, in this short-term experiment, induced hindgut acidosis was not associated with negative effects on milk production and composition, energy balance, or inflammatory response, and was positively associated with milk N efficiency. Similarly, the induced compensated metabolic acidosis was not associated with negative effects on milk production and composition or inflammatory response, and was being positively associated with energy retained as body fat. Long-term studies are needed to confirm these shortterm findings.

\section{ACKNOWLEDGMENTS}

Lianne Alderkamp, Nisola Ayanfe, and Christy de Wildt (students of Wageningen University \& Research, the Netherlands), and the staff of the experimental facilities (Teus Bleyenberg, Wim van Ommeren, and Ries Verkerk) are gratefully acknowledged for their assistance during the implementation of the experiment, as are the laboratory staff of the Animal Nutrition Group. This research was conducted by Wageningen University \& Research (Wageningen Livestock Research, Wageningen, the Netherlands), commissioned and funded by the Ministry of Agriculture, Nature and Food Quality (The Hague, the Netherlands) within the framework of Policy Support Research theme 'Feed4Foodure' (BO31.03-005-001; TKI-AF12039) and by the Vereniging Diervoederonderzoek Nederland (Rijswijk, the Netherlands). The authors have not stated any conflicts of interest.

\section{REFERENCES}

Allen, M. S. 2000. Effects of diet on short-term regulation of feed intake by lactating dairy cattle. J. Dairy Sci. 83:1598-1624. https:// doi.org/10.3168/jds.S0022-0302(00)75030-2.

Amado, L., H. Berends, L. N. Leal, J. Wilms, H. van Laar, W. J. J. Gerrits, and J. Martin-Tereso. 2019. Effect of energy source in calf milk replacer on performance, digestibility, and gut permeability in rearing calves. J. Dairy Sci. 102:3994-4001. https://doi.org/10 .3168/jds.2018-15847.

Aronoff, S. L., K. Berkowitz, B. Shreiner, and L. Want. 2004. Glucose metabolism and regulation: Beyond insulin and glucagon. Diabetes Spectr. 17:183-190. https://doi.org/10.2337/diaspect.17.3.183.

Aschenbach, J. R., S. Bilk, G. Tadesse, F. Stumpff, and G. Gabel. 2009. Bicarbonate-dependent and bicarbonate-independent mechanisms contribute to nondiffusive uptake of acetate in the ruminal epithelium of sheep. Am. J. Physiol. Gastro. Liver Physiol. 296:G1098-G1107. https://doi.org/10.1152/ajpgi.90442.2008.

Bauman, D. E., and J. M. Griinari. 2001. Regulation and nutritional manipulation of milk fat: Low-fat milk syndrome. Livest. Prod. Sci. 70:15-29. https://doi.org/10.1016/S0301-6226(01)00195-6.

Bauman, D. E., and J. M. Griinari. 2003. Nutritional regulation of milk fat synthesis. Annu. Rev. Nutr. 23:203-227. https://doi.org/ 10.1146/annurev.nutr.23.011702.073408.

Bell, A. W. 1995. Regulation of organic nutrient metabolism during transition from late pregnancy to early lactation. J. Anim. Sci. 73:2804-2819. https://doi.org/10.2527/1995.7392804x.
Benedet, A., C. L. Manuelian, A. Zidi, M. Penasa, and M. De Marchi. 2019. Invited review: $\beta$-hydroxybutyrate concentration in blood and milk and its associations with cow performance. Animal 13:1676-1689. https://doi.org/10.1017/S175173111900034X.

Brouns, F., B. Kettlitz, and E. Arrigoni. 2002. Resistant starch and "the butyrate revolution". Trends Food Sci. Technol. 13:251-261. https://doi.org/10.1016/S0924-2244(02)00131-0.

Brown, M. S., C. R. Krehbiel, M. L. Galyean, M. D. Remmenga, J. P. Peters, B. Hibbard, J. Robinson, and W. M. Moseley. 2000. Evaluation of models of acute and subacute acidosis on dry matter intake, ruminal fermentation, blood chemistry, and endocrine profiles of beef steers. J. Anim. Sci. 78:3155-3168. https://doi.org/ $10.2527 / 2000.78123155 x$.

Cant, J. P., D. R. Trout, F. Qiao, and N. G. Purdie. 2002. Milk synthetic response of the bovine mammary gland to an increase in the local concentration of arterial glucose. J. Dairy Sci. 85:494-503. https://doi.org/10.3168/jds.S0022-0302(02)74100-3.

Clark, J. H., H. R. Spires, R. G. Derrig, and M. R. Bennink. 1977. Milk production, nitrogen utilization and glucose synthesis in lactating cows infused postruminally with sodium caseinate and glucose. J. Nutr. 107:631-644. https://doi.org/10.1093/jn/107.4.631.

Constable, P. D. 1999. Clinical assessment of acid-base status. Strong ion difference theory. Vet. Clin. North Am. Food Anim. Pract. 15:447-471. https://doi.org/10.1016/S0749-0720(15)30158-4.

Corey, H. E. 2003. Stewart and beyond: New models of acid-base balance. Kidney Int. 64:777-787. https://doi.org/10.1046/j.1523-1755 .2003.00177.x.

CVB. 2018. Chemische Samenstellingen en Nutritionele Waarden van Voedermiddelen (in Dutch). CVB (Centraal Veevoederbureau).

Danscher, A. M., S. Li, P. H. Andersen, E. Khafipour, N. B. Kristensen, and J. C. Plaizier. 2015. Indicators of induced subacute ruminal acidosis (SARA) in Danish Holstein cows. Acta Vet. Scand. $57: 1-14$.

Duffield, T. 2000. Subclinical ketosis in lactating dairy cattle. Vet. Clin. North Am. Food Anim. Pract. 16:231-253. https://doi.org/ 10.1016/S0749-0720(15)30103-1.

Duffield, T. F., K. D. Lissemore, B. W. McBride, and K. E. Leslie. 2009. Impact of hyperketonemia in early lactation dairy cows on health and production. J. Dairy Sci. 92:571-580. https://doi.org/ 10.3168/jds.2008-1507.

Emery, R. S., L. D. Brown, and J. W. Bell. 1965. Correlation of milk fat with dietary and metabolic factors in cows fed restrictedroughage rations supplemented with magnesium oxide or sodium bicarbonate. J. Dairy Sci. 48:1647-1651. https://doi.org/10.3168/ jds.S0022-0302(65)88543-5.

Emery, R. S., N. Burg, L. D. Brown, and G. N. Blank. 1964. Detection, occurrence, and prophylactic treatment of borderline ketosis with propylene glycol feeding. J. Dairy Sci. 47:1074-1079. https://doi .org/10.3168/jds.S0022-0302(64)88848-2.

Enemark, J. M., R. J. Jørgensen, and P. S. Enemark. 2002. Rumen acidosis with special emphasis on diagnostic aspects of subclinical rumen acidosis: A review. Vet. ir Zootech. 20:16-29.

Enemark, J. M. D. 2008. The monitoring, prevention and treatment of sub-acute ruminal acidosis (SARA): A review. Vet. J. 176:32-43. https://doi.org/10.1016/j.tvjl.2007.12.021.

Enjalbert, F., M. C. Nicot, C. Bayourthe, and R. Moncoulon. 2001. Ketone bodies in milk and blood of dairy cows: Relationship between concentrations and utilization for detection of subclinical ketosis. J. Dairy Sci. 84:583-589. https://doi.org/10.3168/jds.S0022 $-0302(01) 74511-0$.

Ewaschuk, J. B., G. A. Zello, J. M. Naylor, and D. R. Brocks. 2002. Metabolic acidosis: Separation methods and biological relevance of organic acids and lactic acid enantiomers. J. Chromatogr. B Analyt. Technol. Biomed. Life Sci. 781:39-56. https://doi.org/10 .1016/S1570-0232(02)00500-7.

Gant, R. G., W. Sanchez, and R. L. Kincaid. 1998. Effect of anionic salts on selenium metabolism in nonlactating, pregnant dairy cows. J. Dairy Sci. 81:1637-1642. https://doi.org/10.3168/jds .S0022-0302(98)75731-5.

Gärtner, T., V. Zoche-Golob, S. Redlberger, P. Reinhold, and K. Donat. 2019. Acid-base assessment of post-parturient German Hol- 
stein dairy cows from jugular venous blood and urine: A comparison of the strong ion approach and traditional blood gas analysis. PLoS One 14:e0210948. https://doi.org/10.1371/journal.pone .0210948 .

Geishauser, T., K. Leslie, J. Tenhag, and A. Bashiri. 2000. Evaluation of eight cow-side ketone tests in milk for detection of subclinical ketosis in dairy cows. J. Dairy Sci. 83:296-299. https://doi.org/10 .3168/jds.S0022-0302(00)74877-6.

Gerich, J. E., M. A. Charles, and G. M. Grodsky. 1974. Characterization of the effects of arginine and glucose on glucagon and insulin release from the perfused rat pancreas. J. Clin. Invest. 54:833-841. https://doi.org/10.1172/JCI107823.

Gerrits, W. J. J., J. J. G. C. van den Borne, and E. Labussière. 2015. Deriving heat production from gaseous exchange: Validity of the approach. Pages 19-34 in Indirect Calorimetry. Techniques, Computations and Applications. W. J. J. Gerrits and E. Labussière, ed. Wageningen Academic Publishers.

Gressley, T. F., and L. E. Armentano. 2007. Effects of low rumen degradable protein or abomasal fructan infusion on diet digestibility and urinary nitrogen excretion in lactating dairy cows. J. Dairy Sci. 90:1340-1353. https://doi.org/10.3168/jds.S0022 -0302(07)71621-1.

Gressley, T. F., M. B. Hall, and L. E. Armentano. 2011. Ruminant nutrition symposium: Productivity, digestion, and health responses to hindgut acidosis in ruminants. J. Anim. Sci. 89:1120-1130. https://doi.org/10.2527/jas.2010-3460.

Heetkamp, M. J. W., S. J. J. Alferink, T. Zandstra, P. Hendriks, H. van den Brand, and W. J. J. Gerrits. 2015. Design of climate respiration chambers, adjustable to the metabolic mass of subjects. Pages 35-56 in Indirect Calorimetry. Techniques, Computations and Applications. W. J. J. Gerrits and E. Labussière, ed. Wageningen Academic Publishers.

Herrick, K. J., A. R. Hippen, K. F. Kalscheur, D. J. Schingoethe, S. D. Ranathunga, J. L. Anderson, S. C. Moreland, and J. E. van Eys. 2018. Infusion of butyrate affects plasma glucose, butyrate, and $\beta$-hydroxybutyrate but not plasma insulin in lactating dairy cows. J. Dairy Sci. 101:3524-3536. https://doi.org/10.3168/jds .2017-13842.

Hood, V., and R. Tannen. 1994. Maintenance of acid-base homeostasis during ketoacidosis and lactic acidosis. Diabetes Rev. (Alex.) $2: 177-194$

Indrova, E., R. Dolezel, J. Novakova-Mala, A. Pechova, M. Zavadilova, and S. Cech. 2017. Impact of acute metabolic acidosis on the acidbase balance in follicular fluid and blood in dairy cattle. Theriogenology 89:41-46. https://doi.org/10.1016/j.theriogenology.2016 .09 .053 .

International Organization for Standardization. 1998. ISO 9831:1998. Animal feedstuffs, animal products, and feces or urine-Determination of gross caloric values-Bomb calorimeter method. International Organization for Standardization.

International Organization for Standardization. 2013. ISO 9622:2013. Milk and liquid milk products. Guidelines for the application of mid-infrared spectrometry. International Organization for Standardization.

Ireland-Perry, R. L., and C. C. Stallings. 1993. Fecal consistency as related to dietary composition in lactating Holstein cows. J. Dairy Sci. 76:1074-1082. https://doi.org/10.3168/jds.S0022 -0302(93)77436-6.

Kameda, H., T. Abei, S. Nasrallah, and F. L. Iber. 1968. Functional and histological injury to intestinal mucosa produced by hypertonicity. Am. J. Physiol. 214:1090-1095. https://doi.org/10.1152/ ajplegacy.1968.214.5.1090.

Knowlton, K. F., T. E. Dawson, B. P. Glenn, G. B. Huntington, and R. A. Erdman. 1998. Glucose metabolism and milk yield of cows infused abomasally or ruminally with starch. J. Dairy Sci. 81:3248 3258. https://doi.org/10.3168/jds.S0022-0302(98)75889-8.

Laeger, T., C. C. Metges, and B. Kuhla. 2010. Role of $\beta$-hydroxybutyric acid in the central regulation of energy balance. Appetite 54:450 455. https://doi.org/10.1016/j.appet.2010.04.005.

Laffel, L. 1999. Ketone bodies: A review of physiology pathophysiology and application of monitoring diabetes. Diabetes Metab. Res. Rev.
15:412-426. https://doi.org/10.1002/(SICI)1520-7560(199911/ 12)15:6<412::AID-DMRR72>3.0.CO:2-8.

Li, S., E. Khafipour, D. O. Krause, A. Kroeker, J. C. RodriguezLecompte, G. N. Gozho, and J. C. Plaizier. 2012. Effects of subacute ruminal acidosis challenges on fermentation and endotoxins in the rumen and hindgut of dairy cows. J. Dairy Sci. 95:294-303. https://doi.org/10.3168/jds.2011-4447.

Lv, S., D. Li, J. Xing, Y. Ma, S. Huang, and J. Li. 2006. Effects of extrusion of corn on growth performance, nutrient digestibility and short-chain fatty acid profiles in the hindgut of weaned piglets. Arch. Anim. Nutr. 60:170-179. https://doi.org/10.1080/ 17450390600562759 .

Madison, L. L., D. Mebane, H. R. Unger, and A. Lochner. 1964. The hypoglycemic action of ketones. II. Evidence for a stimulatory feedback of ketones on the pancreatic beta cells. J. Clin. Invest. 43:408-415. https://doi.org/10.1172/JCI104925.

Mao, S., R. Zhang, D. Wang, and W. Zhu. 2012. The diversity of the fecal bacterial community and its relationship with the concentration of volatile fatty acids in the feces during subacute rumen acidosis in dairy cows. BMC Vet. Res. 8:237. https://doi.org/10 .1186/1746-6148-8-237.

Matthé, A., P. Lebzien, I. Hric, G. Flachowsky, and A. Sommer. 2001. Effect of starch application into the proximal duodenum of ruminants on starch digestibility in the small and total intestine. Arch. Anim. Nutr. 55:351-369. https://doi.org/10.1080/ 17450390109386202.

McArt, J. A. A., D. V. Nydam, and G. R. Oetzel. 2012. Epidemiology of subclinical ketosis in early lactation dairy cattle. J. Dairy Sci. 95:5056-5066. https://doi.org/10.3168/jds.2012-5443.

Mebane, D., and L. L. Madison. 1962. The hypoglycemic effect of ketone bodies. J. Clin. Invest. 41:1383

Mesgaran, S. D., B. Kühla, R. Baumont, G. Cantalapiedra-Hijar, P. Noziére, P. Lund, D. Humphries, and J. Dijkstra. 2020. Nutrient digestibility and balance studies. In Methods in Cattle Physiology and Behaviour - Recommendations from the SmartCow Consortium. S. D. Mesgaran, R. Baumont, L. Munksgaard, D. Humphries, E. Kennedy, J. Dijkstra, R. Dewhurst, H. Ferguson, M. Terré, and B. Kühla, ed. Publisso.

Mills, J. A. N., J. France, and J. Dijkstra. 1999. A review of starch digestion in the lactating dairy cow and proposals for a mechanistic model: 1. Dietary starch characterisation and ruminal starch digestion. J. Anim. Feed Sci. 8:291-340. https://doi.org/10.22358/ jafs/68938/1999.

Moharrery, A., M. Larsen, and M. R. Weisbjerg. 2014. Starch digestion in the rumen, small intestine, and hind gut of dairy cows - A meta-analysis. Anim. Feed Sci. Technol. 192:1-14. https://doi.org/ 10.1016/j.anifeedsci.2014.03.001.

Morris, D. L., L. R. Rebelo, P. A. Dieter, and C. Lee. 2018. Validating intrinsic markers and optimizing spot sampling frequency to estimate fecal outputs. J. Dairy Sci. 101:7980-7989. https://doi.org/ 10.3168/jds.2018-14717.

Mulligan, F. J., and M. L. Doherty. 2008. Production diseases of the transition cow. Vet. J. 176:3-9. https://doi.org/10.1016/j.tvjl.2007 .12 .018 .

Nichols, K., A. Bannink, S. Pacheco, H. J. van Valenberg, J. Dijkstra, and H. van Laar. 2018. Feed and nitrogen efficiency are affected differently but milk lactose production is stimulated equally when isoenergetic protein and fat is supplemented in lactating dairy cow diets. J. Dairy Sci. 101:7857-7870. https://doi.org/10.3168/jds .2017-14276.

Nichols, K., J. Dijkstra, H. van Laar, S. Pacheco, H. J. van Valenberg, and A. Bannink. 2019. Energy and nitrogen partitioning in dairy cows at low or high metabolizable protein levels is affected differently by postrumen glucogenic and lipogenic substrates. J. Dairy Sci. 102:395-412. https://doi.org/10.3168/jds.2018-15249.

Owens, F. N., and C. F. Hanson. 1992. External and internal markers for appraising site and extent of digestion in ruminants. J. Dairy Sci. 75:2605-2617. https://doi.org/10.3168/jds.S0022 $-0302(92) 78023-0$. 
Owens, F. N., R. A. Zinn, and Y. K. Kim. 1986. Limits to starch digestion in the ruminant small intestine. J. Anim. Sci. 63:1634-1648. https://doi.org/10.2527/jas1986.6351634x.

Plaizier, J. C., M. Danesh Mesgaran, H. Derakhshani, H. Golder, E. Khafipour, J. L. Kleen, I. Lean, J. Loor, G. Penner, and Q. Zebeli. 2018. Review: Enhancing gastrointestinal health in dairy cows. Animal 12(Suppl. 2):s399-s418. https://doi.org/10.1017/ S1751731118001921.

Plaizier, J. C., S. Li, A. M. Danscher, H. Derakshani, P. H. Andersen, and E. Khafipour. 2017. Changes in microbiota in rumen digesta and feces due to a grain-based subacute ruminal acidosis (SARA) challenge. Microb. Ecol. 74:485-495. https://doi.org/10.1007/ s00248-017-0940-z.

Reynolds, C. K. 2006. Production and metabolic effects of site of starch digestion in dairy cattle. Anim. Feed Sci. Technol. 130:7894. https://doi.org/10.1016/j.anifeedsci.2006.01.019.

Reynolds, C. K., S. B. Cammell, D. J. Humphries, D. E. Beever, J. D. Sutton, and J. R. Newbold. 2001. Effects of postrumen starch infusion on milk production and energy metabolism in dairy cows. J. Dairy Sci. 84:2250-2259. https://doi.org/10.3168/jds.S0022 -0302(01)74672-3.

Reynolds, C. K., D. J. Humphries, S. B. Cammell, J. Benson, J. D. Sutton, and D. E. Beever. 1998. Effects of abomasal wheat starch infusion on splanchnic metabolism and energy balance of lactating dairy cows. Page 39 in Energy Metabolism of Farm Animals, Proceedings of the 14th Symposium on Energy Metabolism. K. J. McCracken, E. F. Unsworth, A. R. G. Wylie, ed. CAB International.

Reynolds, C. K., J. D. Sutton, and D. E. Beever. 1997. Effects of feeding starch to dairy cattle on nutrient availability and production. Pages 105-134 in Recent Advances in Animal Nutrition, Proc. 30th University of Nottingham Conference for Feed Manufacturers. P. C. Garnsworthy and J. Wiseman, ed. University of Nottingham Press.

Rius, A. G., J. A. D. R. N. Appuhamy, J. Cyriac, D. Kirovski, O. Becvar, J. Escobar, M. L. McGilliard, B. J. Bequette, R. M. Akers, and M. D. Hanigan. 2010. Regulation of protein synthesis in mammary glands of lactating dairy cows by starch and amino acids. J. Dairy Sci. 93:3114-3127. https://doi.org/10.3168/jds.2009-2743.

Ruoff, J., S. Borchardt, and W. Heuwieser. 2017. Short communication: Associations between blood glucose concentration, onset of hyperketonemia, and milk production in early lactation dairy cows. J. Dairy Sci. 100:5462-5467. https://doi.org/10.3168/jds 2016-12237.

Santschi, D. E., R. Lacroix, J. Durocher, M. Duplessis, R. K. Moore, and D. M. Lefebvre. 2016. Prevalence of elevated milk $\beta$-hydroxybutyrate concentrations in Holstein cows measured by Fourier-transform infrared analysis in dairy herd improvement milk samples and association with milk yield and components. J. Dairy Sci. 99:9263-9270. https://doi.org/10.3168/jds.2016-11128.

Schlumbohm, C., and J. Harmeyer. 2003. Hypocalcemia reduces endogenous glucose production in hyperketonemic sheep. J. Dairy Sci. 86:1953-1962. https://doi.org/10.3168/jds.S0022-0302(03)73783 -7 .

Simensen, E., K. Halse, P. Gillund, and B. Lutnœs. 1990. Ketosis treatment and milk yield in dairy cows related to milk acetoacetate levels. Acta Vet. Scand. 31:433-440. https://doi.org/10.1186/ BF03547525.

Tamminga, S., P. A. Luteijn, and R. G. M. Meijer. 1997. Changes in composition and energy content of liveweight loss in dairy cows with time after parturition. Livest. Prod. Sci. 52:31-38. https:// doi.org/10.1016/S0301-6226(97)00115-2.

Titgemeyer, E. C., C. K. Armendariz, D. J. Bindel, R. H. Greenwood, and C. A. Löest. 2001. Evaluation of titanium dioxide as a digestibility marker for cattle. J. Anim. Sci. 79:1059-1063. https://doi .org/10.2527/2001.7941059x.

Vagnoni, D. B., and G. R. Oetzel. 1998. Effects of dietary cationanion difference on the acid-base status of dry cows. J. Dairy Sci. 81:1643-1652. https://doi.org/10.3168/jds.S0022-0302(98)75732 -7 .

Van Duinkerken, G., M. C. Blok, A. Bannink, J. W. Cone, J. Dijkstra, A. M. van Vuuren, and S. Tamminga. 2011. Update of the Dutch protein evaluation system for ruminants: The DVE/ OEB2010 system. J. Agric. Sci. 149:351-367. https://doi.org/10 $.1017 /$ S0021859610000912.

Van Es, A. J. H. 1978. Feed evaluation for ruminants. I. The systems in use from May 1977-onwards in the Netherlands. Livest. Prod. Sci. 5:331-345. https://doi.org/10.1016/0301-6226(78)90029-5.

van Gastelen, S., E. C. Antunes-Fernandes, K. A. Hettinga, G. Klop, S. J. J. Alferink, W. H. Hendriks, and J. Dijkstra. 2015. Enteric methane production, rumen volatile fatty acid concentrations, and milk fatty acid composition in lactating Holstein-Friesian cows fed grass silage- or corn silage-based diets. J. Dairy Sci. 98:1915-1927. https://doi.org/10.3168/jds.2014-8552.

van Gastelen, S., J. Dijkstra, K. Nichols, and A. Bannink. 2021. Abomasal infusion of ground corn and ammonium chloride in early lactating Holstein-Friesian dairy cows to induce hindgut and metabolic acidosis. J. Dairy Sci. 104:4174-4191. https://doi.org/ 10.3168/jds.2020-19300.

van Knegsel, A. T. M., H. van den Brand, J. Dijkstra, W. M. van Straalen, M. J. W. Heetkamp, S. Tamminga, and B. Kemp. 2007a. Dietary energy source in dairy cows in early lactation: Energy partitioning and milk composition. J. Dairy Sci. 90:1467-1476. https: //doi.org/10.3168/jds.S0022-0302(07)71632-6.

van Knegsel, A. T. M., H. van den Brand, J. Dijkstra, W. M. van Straalen, R. Jorritsma, S. Tamminga, and B. Kemp. 2007b. Effect of glucogenic vs. lipogenic diets on energy balance, blood metabolites, and reproduction in primiparous and multiparous dairy cows in early lactation. J. Dairy Sci. 90:3397-3409. https://doi.org/10 $.3168 /$ jds.2006-837.

van Zijderveld, S. M., B. Fonken, J. Dijkstra, W. J. J. Gerrits, H. B. Perdok, W. Fokkink, and J. R. Newbold. 2011. Effects of a combination of feed additives on methane production, diet digestibility, and animal performance in lactating dairy cows. J. Dairy Sci. 94:1445-1454. https://doi.org/10.3168/jds.2010-3635.

Vanholder, T., J. Papen, R. Bemers, G. Vertenten, and A. C. B. Berge. 2015. Risk factors for subclinical and clinical ketosis and association with production parameters in dairy cows in the Netherlands. J. Dairy Sci. 98:880-888. https://doi.org/10.3168/jds.2014-8362.

Williams, E. J. 1949. Experimental designs balanced for the estimation of residual effects of treatments. Aust. J. Sci. Res., A 2:149-168. https://doi.org/10.1071/CH9490149.

Wilms, J., H. Berends, and J. Martín-Tereso. 2019. Hypertonic milk replacers increase gastrointestinal permeability in healthy dairy calves. J. Dairy Sci. 102:1237-1246. https://doi.org/10.3168/jds .2018-15265.

Zaaijer, D., W. D. J. Kremer, and J. P. T. M. Noordhuizen. 2001. Consistentie van verse koemest. Page 54 in Koe signalen. Praktijkgids voor koegericht management. J. Hulsen, ed. Roodbont Uitgeverij.

Zarrin, M., L. De Matteis, M. C. M. B. Vernay, O. Wellnitz, H. A. van Dorland, and R. M. Bruckmaier. 2013. Long-term elevation of $\beta$-hydroxybutyrate in dairy cows through infusion: Effects on feed intake, milk production, and metabolism. J. Dairy Sci. 96:29602972. https://doi.org/10.3168/jds.2012-6224.

Zarrin, M., O. Wellnitz, H. A. van Dorland, J. J. Gross, and R. M. Bruckmaier. 2014. Hyperketonemia during lipopolysaccharide-induced mastitis affects systemic and local intramammary metabolism in dairy cows. J. Dairy Sci. 97:3531-3541. https://doi.org/10 $.3168 /$ jds.2013-7480.

Zimpel, R., M. B. Poindexter, A. Vieira-Neto, E. Block, C. D. Nelson, C. R. Staples, W. W. Thatcher, and J. E. P. Santos. 2018. Effect of dietary cation-anion difference on acid-base status and dry matter intake in dry pregnant cows. J. Dairy Sci. 101:8461-8475. https:// doi.org/10.3168/jds.2018-14748.

\section{ORCIDS}

Sanne van Gastelen ำ https://orcid.org/0000-0003-4547-8449 Jan Dijkstra @ https://orcid.org/0000-0003-3728-6885 Sven J. J. Alferink @ https://orcid.org/0000-0001-8526-2437 Kelly Nichols @ https://orcid.org/0000-0001-6062-7460 